\title{
THE
}

\section{Below the Disappearing Marshes of an Urban Estuary: Historic Nitrogen Trends and Soil Structure}

\author{
Cathleen Wigand \\ Charles T. Roman \\ Earl Davey \\ Mark Stolt \\ University of Rhode Island, mstolt@uri.edu \\ Roxanne Johnson
}

See next page for additional authors

Follow this and additional works at: https://digitalcommons.uri.edu/nrs_facpubs

Terms of Use

All rights reserved under copyright.

\section{Citation/Publisher Attribution}

Wigand, C. , Roman, C. T., Davey, E. , Stolt, M. , Johnson, R. , Hanson, A. , Watson, E. B., Moran, S. B., Cahoon, D. R., Lynch, J. C. and Rafferty, P. (2014), Below the disappearing marshes of an urban estuary: historic nitrogen trends and soil structure. Ecological Applications, 24: 633-649. doi: 10.1890/13-0594.1 Available at: http://dx.doi.org/10.1890/13-0594.1

This Article is brought to you for free and open access by the Natural Resources Science at DigitalCommons@URI. It has been accepted for inclusion in Natural Resources Science Faculty Publications by an authorized administrator of DigitalCommons@URI. For more information, please contact digitalcommons-group@uri.edu. 


\section{Authors}

Cathleen Wigand, Charles T. Roman, Earl Davey, Mark Stolt, Roxanne Johnson, Alana Hanson, Elizabeth B. Watson, S. Bradley Moran, Donald R. Cahoon, James C. Lynch, and Patricia Rafferty 


\title{
Below the disappearing marshes of an urban estuary: historic nitrogen trends and soil structure
}

\author{
Cathleen Wigand, ${ }^{1,8}$ Charles T. Roman, ${ }^{2}$ Earl Davey, ${ }^{1}$ Mark Stolt,${ }^{3}$ Roxanne Johnson, ${ }^{1}$ Alana Hanson, ${ }^{1}$ \\ Elizabeth B. Watson, ${ }^{1}$ S. Bradley Moran, ${ }^{4}$ Donald R. Cahoon, ${ }^{5}$ James C. Lynch, ${ }^{6}$ and Patricia Rafferty ${ }^{7}$ \\ ${ }^{1}$ U.S. EPA Office of Research and Development, National Health and Environmental Effects Research Lab, Atlantic Ecology Division, \\ Narragansett, Rhode Island 02882 USA \\ ${ }^{2}$ National Park Service, North Atlantic Coast Cooperative Ecosystem Studies Unit, University of Rhode Island, \\ Narragansett, Rhode Island 02882 USA \\ ${ }^{3}$ Department of Natural Resources Science, 112 Kingston Coastal Institute, 1 Greenhouse Road, University of Rhode Island, \\ Kingston, Rhode Island 02881 USA \\ ${ }^{4}$ Graduate School of Oceanography, University of Rhode Island, Narragansett, Rhode Island 02882-1197 USA \\ ${ }^{5}$ United States Geological Survey, U.S. Geological Survey, Patuxent Wildlife Research Center, 10300 Baltimore Avenue, \\ BARC-East, Building 308, Beltsville, Maryland 20705 USA \\ ${ }^{6}$ National Park Service, Northeast Coastal and Barrier Network, 4598 MacArthur Boulevard NW, Washington, D.C. 20007 USA \\ ${ }^{7}$ National Park Service, Northeast Region, 120 Laurel Street, Patchogue, New York 11772 USA
}

Abstract. Marshes in the urban Jamaica Bay Estuary, New York, USA are disappearing at an average rate of $13 \mathrm{ha} / \mathrm{yr}$, and multiple stressors (e.g., wastewater inputs, dredging activities, groundwater removal, and global warming) may be contributing to marsh losses. Among these stressors, wastewater nutrients are suspected to be an important contributing cause of marsh deterioration. We used census data, radiometric dating, stable nitrogen isotopes, and soil surveys to examine the temporal relationships between human population growth and soil nitrogen; and we evaluated soil structure with computer-aided tomography, surface elevation and sediment accretion trends, carbon dioxide emissions, and soil shear strength to examine differences among disappearing (Black Bank and Big Egg) and stable marshes (JoCo). Radiometric dating and nitrogen isotope analyses suggested a rapid increase in human wastewater nutrients beginning in the late 1840s, and a tapering off beginning in the 1930s when wastewater treatment plants (WWTPs) were first installed. Current WWTPs nutrient loads to Jamaica Bay are approximately $13995 \mathrm{~kg} \mathrm{~N} / \mathrm{d}$ and $2767 \mathrm{~kg} \mathrm{P} / \mathrm{d}$. At Black Bank, the biomass and abundance of roots and rhizomes and percentage of organic matter on soil were significantly lower, rhizomes larger in diameter, carbon dioxide emission rates and peat particle density significantly greater, and soil strength significantly lower compared to the stable JoCo Marsh, suggesting Black Bank has elevated decomposition rates, more decomposed peat, and highly waterlogged peat. Despite these differences, the rates of accretion and surface elevation change were similar for both marshes, and the rates of elevation change approximated the long term relative rate of sea level rise estimated from tide gauge data at nearby Sandy Hook, New Jersey. We hypothesize that Black Bank marsh kept pace with sea level rise by the accretion of material on the marsh surface, and the maintenance of soil volume through production of larger diameter rhizomes and swelling (dilation) of waterlogged peat. JoCo Marsh kept pace with sea-level rise through surface accretion and soil organic matter accumulation. Understanding the effects of multiple stressors, including nutrient enrichment, on soil structure, organic matter accumulation, and elevation change will better inform management decisions aimed at maintaining and restoring coastal marshes.

Key words: belowground biomass; carbon dioxide emissions; computer-aided tomography (CT) imaging; eutrophication; Jamaica Bay; marsh loss; peat swelling; radiometric dating; sea level rise; shear stress.

Each soil has its own history. Like a river, a mountain, a forest, or any natural thing, its present condition is due to the influence of many things and events of the past.

—Charles E. Kellogg (1956)

Manuscript received 28 March 2013; revised 19 September 2013; accepted 7 October 2013. Corresponding Editor: C. B. Craft.

${ }^{8}$ E-mail: wigand.cathleen@epa.gov

\section{INTRODUCTION}

The extent of the Jamaica Bay salt marsh islands was about 950 ha in the 1950s with only about 355 ha remaining in 2003 (National Park Service 2007). Marsh loss rates have accelerated in recent decades, averaging 13 ha/yr from 1989 to 2003 (National Park Service 2007). Many stressors are proposed to contribute to marsh loss in the Jamaica Bay Estuary including wastewater inputs, dredging and filling activities, groundwater removal, and global warming with its 
associated changes (e.g., accelerated sea level rise, increase in soil temperatures [Hartig et al. 2002, Kolker 2005, Swanson and Wilson 2008, National Park Service 2007]). Extensive dredging in the Jamaica Bay Estuary increased the tidal range of the system, and as a result, the water levels at high tide over the marshes have increased by $56-78 \%$ above that expected by regional sea level rise alone (Swanson and Wilson 2008). In addition, a hardening of the bay's perimeter from increased residential and commercial development, and the channeling of overland flow through storm sewers and combined sewer overflows have presumably reduced the overall sediment load to the bay and marshes (National Park Service 2007). Among these multiple stressors, human wastewater is suspected to be an important contributing cause of marsh deterioration. In this study, we focus on the high loads of nutrients in Jamaica Bay as a driver of change in belowground marsh soil structure and processes, and subsequent marsh loss.

Space-for-time substitution studies in coastal estuaries have shown that human wastewater nitrogen contributes to community and system level changes in urban salt marsh ecosystems (McClelland and Valiela 1998, Wigand et al. 2003, Bannon and Roman 2008, Wigand 2008). A large scale, nutrient enrichment study in the Plum Island Estuary (Massachusetts) has shown that additions of dissolved $\mathrm{N}$ and phosphorus (P) to 15-20 times over background have resulted in noticeable and significant deterioration of coastal wetlands (Deegan et al. 2012). Some responses noticed in long-term, large (e.g., Plum Island, Massachusetts), and meso-scale (e.g., Great Sippewisset marsh, Massachusetts) nutrient fertilization experiments in the northeast United States are increased aboveground biomass, decreased belowground biomass, and loss in marsh soil strength (Valiela et al. 1976, Turner et al. 2009, Turner 2011, Deegan et al. 2012). A significant inverse relationship between nutrient enrichment and belowground roots and rhizomes has been reported for marshes in the western Atlantic and the Gulf of Mexico (Darby and Turner 2008). Langley et al. (2009) demonstrated that nitrogen fertilization reduces belowground growth and also inhibits the stimulatory effect of elevated atmospheric carbon dioxide on root growth. Increases in marsh soil carbon dioxide emission rates have been detected in short- and long-term nutrient fertilization experiments (Morris and Bradley 1999, Anisfeld and Hill 2012), as well as in N-loading gradient surveys (Wigand et al. 2009). Nutrient fertilization (nitrogen and/or phosphorus) enhanced microbial mineralization and decomposition processes in the Everglades (Qualls and Richardson 2008), arctic tundra soils (Mack et al. 2004), and organic rich salt marsh soils (Deegan et al. 2012).

Wastewater nitrogen is associated with human settlements. New York City (NYC) became the first stop in the United States for millions of immigrants in the late 1800s (Damon 1981), and many chose to settle in communities surrounding Jamaica Bay. Since the late 1840 s, the bay has received wastewater either as raw sewage or effluent from wastewater treatment plants, first constructed in the 1930s. Currently, the New York City Department of Environmental Protection operates four municipal wastewater treatment plants (WWTPs) that discharge treated wastewater into Jamaica Bay (Fig. 1), at rates of about $13995 \mathrm{~kg} \mathrm{~N} / \mathrm{d}$ (Benotti et al. 2007) and $2767 \mathrm{~kg} \mathrm{P} / \mathrm{d}$ (New York City Department of Environmental Protection 2007). Prior to development (pre 1900s), nitrogen primarily received from subsurface groundwater flow was estimated at $36 \mathrm{~kg} \mathrm{~N} / \mathrm{d}$ (Benotti et al. 2007). In the 1990s, the Jamaica Bay estuary was described as having poor water quality with total dissolved inorganic nitrogen concentrations ranging from $0.11-2.15 \mathrm{mg} / \mathrm{L}$ and total phosphorus ranging from $0.10-0.60 \mathrm{mg} / \mathrm{L}$, which exceeded the potentially limiting nutrient $(\mathrm{N}+\mathrm{P})$ concentrations to primary production, causing the bay to be eutrophic (O'Shea and Brosnan 2000). Human wastewater N inputs to coastal waters are detected as enriched stable nitrogen isotope ratios in biota among sub-estuaries with varying watershed development and nitrogen loads (e.g., McClelland et al. 1997, McKinney et al. 2001, Bannon and Roman 2008), and at single sites with depth in radiometrically dated cores (Maren and Struck 1997, Struck et al. 2000, Castro et al. 2007). In this study, we examined for a historic cultural eutrophication signal in Jamaica Bay marsh cores using stable nitrogen isotopes and radiometric dating.

In an earlier study in Jamaica Bay, we verified the use of computer-aided tomography (CT) imaging to quantify marsh soil structure, i.e., coarse roots, rhizomes, and peat in salt marshes (Davey et al. 2011, Wigand and Roman 2012). In the present study, we expanded the belowground surveys to more locations and looked for differences in the soil morphology in disappearing, stable, and restored marshes. In addition, we tested for differences in marsh carbon dioxide emissions and shear strength between stable and disappearing marshes. We examined the soil percent nitrogen and nitrogen isotope ratios in radiometrically dated cores to test the premise that cultural eutrophication might contribute to the decline of Jamaica Bay marshes, and measured the marsh surface accretion and elevation change to examine if the marshes are keeping up with sea level rise.

\section{Methods}

\section{Watershed and marsh descriptions}

The Jamaica Bay Estuary is located at the west end of Long Island, New York, USA. The $313-\mathrm{km}^{2}$ watershed includes parts of Kings (Brooklyn, $102 \mathrm{~km}^{2}$ ), Queens $\left(134 \mathrm{~km}^{2}\right)$, and Nassau $\left(77 \mathrm{~km}^{2}\right)$ counties (Fig. 1). Historic population and U.S. Census data were used to estimate the population size in the watershed over time (Greene and Harrington 1932, Forstall 1996, U.S. Census 2000). Census block data were available for year 2000 and used to estimate the watershed popula- 


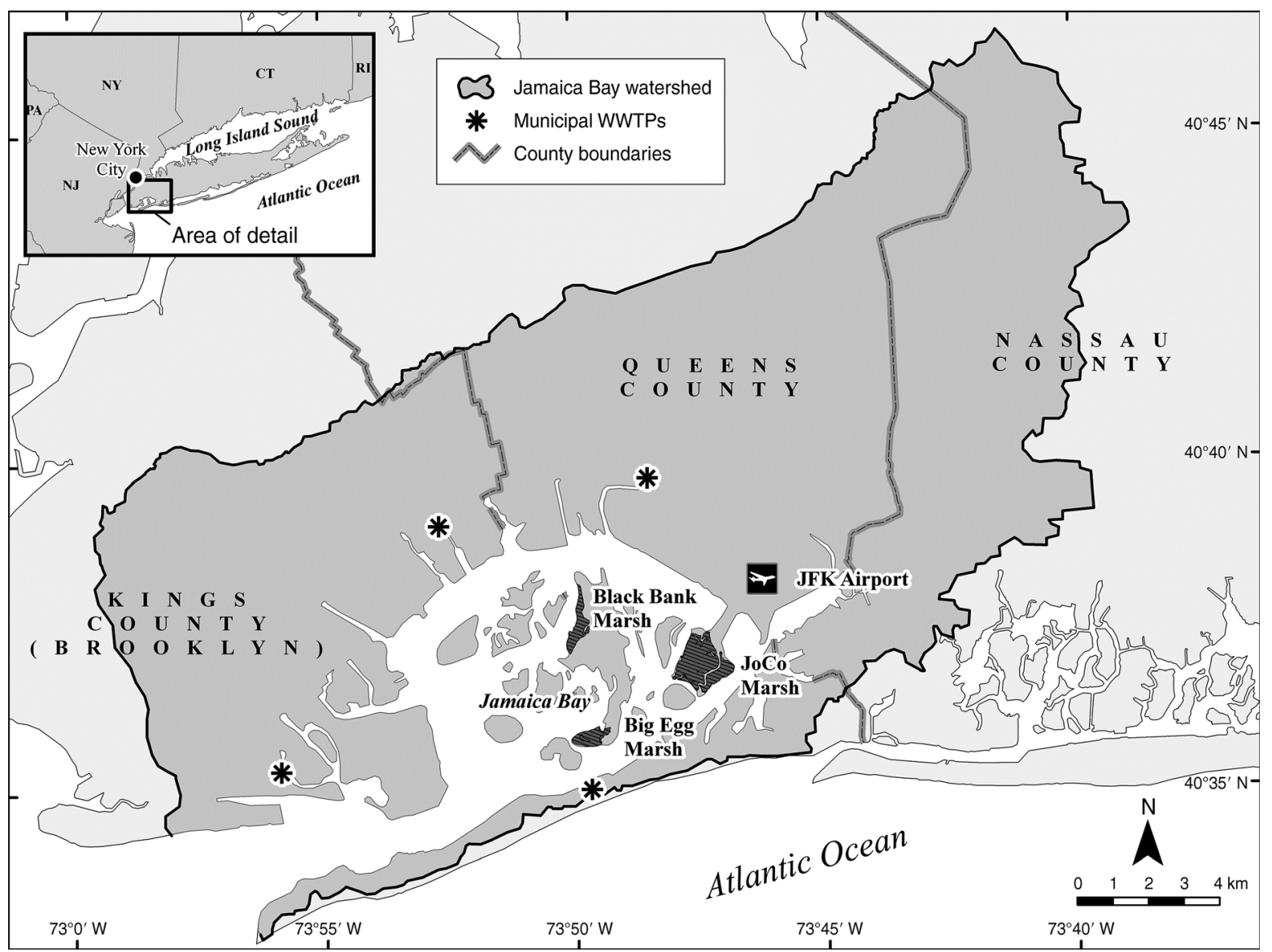

FIG. 1. Location of the marsh study sites, waste water treatment plants (WWTP), and counties in the Jamaica Bay (New York) watershed. The inset shows the location of the more detailed map in the region. Abbreviations are New Jersey, NJ; New York, NY; Pennsylvania, PA; Connecticut, CT; and Rhode Island, RI.

tion. For each census year 1790-1990, the proportion of area of each county (excluding the area of the marsh islands) located within the boundaries of the watershed was multiplied by the total number of people in the respective county, and then summed for a total watershed population. The pre-1790 population was estimated from historical records (Greene and Harrington 1932).

We studied two disappearing marsh island sites (Black Bank and Big Egg), a restored section of the Big Egg Marsh and a relatively stable marsh (JoCo Marsh) that are located within Jamaica Bay (Fig. 1). We initially sampled the four sites to evaluate trends in the belowground structure among marshes in different stages of deterioration and recovery, and then focused on just two of the marshes (JoCo Marsh and Black Bank) with more detailed measures to see if there were significant differences in belowground structure and processes between a stable site and a deteriorating site. We chose Black Bank as the deteriorating marsh, because we wanted a marsh that was relatively early in the deterioration process. Also, we did not have the resources to conduct detailed measures at all four of the sites.

The disappearing Black Bank and Big Egg Spartina alterniflora marshes are characterized by deteriorating creek-bank edges and marsh platforms that are breaking apart (Hartig et al. 2002). Marsh elevations measured in 2012 varied among the marshes with JoCo located $8 \mathrm{~cm}$ above mean high water (MHW), Black Bank at $17 \mathrm{~cm}$ below, Big Egg at $55 \mathrm{~cm}$ below, and the restored Big Egg at $3 \mathrm{~cm}$ below. The restored area of the Big Egg marsh (0.8 ha) was supplemented with approximately $45 \mathrm{~cm}$ of sediment using a self-propelled swinging-ladder dredge and sediment-spray technique in 2003 (Rafferty et al. 2010).

\section{Elevation measures and surface elevation tables}

Vertical accretion and surface elevation change were measured at JoCo and Black Bank marshes using the surface elevation table-marker horizon (SET-MH) method (Cahoon et al. 1995, 2002). These data were collected in the same area as the computer-aided tomography (CT) imaging and radiometric analysis in 2006 and 2007. 
Three SET-MH stations were installed in 2002 at the Black Bank marsh, and three others were installed in the $S$. alterniflora zone at the eastern end of the JoCo marsh in 2006 to monitor changes in marsh surface elevation. Benchmark pipes were driven to substantial resistance $(15-22 \mathrm{~m})$ at both sites, and the marsh elevation was measured one to three times per year (Boumans and Day 1993, Cahoon et al. 2002). Three $\left(0.25-\mathrm{m}^{2}\right)$ sand or feldspar clay marker horizons (Cahoon and Turner 1989) were established in the immediate vicinity of each of the three surface elevation tables. Marker horizons, installed to measure marsh surface accretion trends, were sampled simultaneously with the elevation measurements.

\section{Marsh soil carbon dioxide emission rates}

Carbon dioxide emissions from bare marsh soils between $S$. alterniflora culms were measured in August 2006 and 2007 at the Black Bank and JoCo marshes with a Li-Cor (8100; Li-Cor, Lincoln, Nebraska, USA) $\mathrm{CO}_{2}$ flux system and dome using standard methods (e.g., Howes et al. 1985, Wigand et al. 2009). Polyvinylchloride (PVC) collars (10 cm diameter) were placed in the soil near low tide at least 15 minutes before in situ sampling was conducted. The instrument uses an infrared detector to measure changes in carbon dioxide in the dome within short (5-minute) incubations. Carbon dioxide emissions at each marsh location were measured in five areas located at least $0.5 \mathrm{~m}$ apart. Occasionally, when completely bare areas could not be found between culms, stems (one to three) in the sampling area were cut and plugged with clear silicone gel to prevent gas exchange through lacunae (Wigand et al. 2009).

\section{Quantification of stems, roots, rhizomes, and organic matter}

Large-diameter (15 cm diameter by $30 \mathrm{~cm}$ depth) soil cores vegetated with $S$. alterniflora were collected with a PVC cylinder during slack low tide in August 2006 and 2007. The cylinder was hammer driven into the soil and extracted with a shovel. Cores were imaged using CT and, in 2006, single cores from JoCo, Black Bank, Big Egg, and restored Big Egg marshes were subsequently used for soil morphological descriptions. The belowground biomass and structure (roots, rhizomes, and peat), aboveground-to-belowground ratios, and soil organic matter were assessed in 2007 at the Black Bank and JoCo marshes. Cores were collected from the creekbank, mid-marsh, and high-marsh interior locations $(n=$ 3 locations for each) at each site. Plant stems were clipped, dried to a constant mass at $80^{\circ} \mathrm{C}$, and weighed. Roots and rhizomes were separated from one-half of the soil core using a hydropneumatic root washer (Gillison's Variety Fabrication, Benzonia, Michigan, USA), and then oven dried to a constant mass. The second half of the core was sliced every $3 \mathrm{~cm}$ to a depth of $21 \mathrm{~cm}$. A subsample $(4 \times 4 \times 3 \mathrm{~cm})$ from each depth was dried, sieved, ground with mortar and pestle, and ashed at $550^{\circ} \mathrm{C}$ for $3 \mathrm{~h}$ to determine the percentage of organic matter in the soil using loss on ignition (Heiri et al. 1999). At each depth from cores collected from the midmarsh locations, a second subsample was dried, sieved, and analyzed for percent carbon and nitrogen on a ThermoFinnigan Flash elemental analyzer (San Jose, California, USA). Percent phosphorus was determined by digesting an ashed sample with $1 \mathrm{~mol} / \mathrm{L} \mathrm{HCl}$ and measuring total phosphorus with standard colorimetric methods on a Thermo Spectronic Genesys 2 spectrophotometer (Rochester, New York, USA; Strickland and Parsons 1972, Aspila et al. 1976). Dry bulk density, percent carbon, percent nitrogen, percent phosphorus, $\mathrm{N}: \mathrm{P}$ molar ratios, and $\mathrm{C}: \mathrm{N}$ molar ratios were determined for each depth. Coring at the JoCo and Black Bank marshes was paired with descriptions of vegetation cover using the point intercept method and $1-\mathrm{m}^{2}$ quadrats ( $n=3$ for each location). The heights of the 10 tallest $S$. alterniflora plants in the quadrats were also recorded.

A GE Medical Systems model Light Speed16 CT scanner (Milwaukee, Wisconsin, USA) with an X-ray tube current of 265 milliamps and voltage of 140 kilovolts was used to examine the belowground structure of the marsh cores following the CT methodology of Davey et al. (2011). Calibration rods of air, water, and glass were placed into the cores to provide reference standards to estimate the specific particle densities of the coarse roots and rhizomes and peat. The cores were spirally scanned in a horizontal position from the top to the bottom of the core with the resolution set at a slice thickness of $0.625 \mathrm{~mm}$. We were able to quantify the volume and abundances of coarse roots and rhizomes and the volume and wet mass of the peat using the estimated densities for each soil component. We defined peat as dead roots and rhizomes and decomposing organic matter. Changes in the quality of the peat would be reflected in the CT peat particle density, peat volume, and peat mass as well as in the accumulation of organic matter. There is a significant inverse relationship of CT peat particle density and percent organic matter in salt marsh soils (Davey et al. 2011), and the CT peat particle density increases with increasing water content. Since degrading peat would be highly waterlogged and decomposed, it would have an increased peat particle density and a loss in organic matter.

The coarse roots were defined as having diameters greater than or equal to $1 \mathrm{~mm}$ but less than $2 \mathrm{~mm}$, and rhizomes as having diameters greater than or equal to 2 $\mathrm{mm}$. The CT image analyses had enough resolution to quantify roots greater than $1 \mathrm{~mm}$ in width using these methods. The belowground structure was reported for shallow $(0-10 \mathrm{~cm})$ and deep sections $(10-20 \mathrm{~cm})$ to examine for differences in the more active shallow root zone compared with the deeper soils.

The soil macromorphology included descriptions of horizons, matrix color, and texture using standard 
methods (Schoeneberger et al. 2002). The three major horizons described were the $\mathrm{O}$, $\mathrm{A}$, and $\mathrm{C}$ horizons. Briefly, the $\mathrm{O}$ horizons are organic layers with fresh and decaying plant residues typically at the soil surface. The A horizons are layers of mineral materials near the soil surface in which organic matter is accumulated, mixed, and humified. The $\mathrm{C}$ horizons are mineral layers unaltered by soil-forming processes. The soil micromorphology was described using thin sections $(5.1 \times 7.6 \mathrm{~cm})$ prepared from undisturbed samples collected from the center of the upper $10 \mathrm{~cm}$ of the core. These samples were air dried and impregnated with an epoxy resin before cutting the thin sections (Spectrum Petrographics, Vancouver, Washington, USA). The thin sections were described following the micromorphological terminology of Bullock et al. (1985), Stoops (2003), and Stolt and Lindbo (2010). Fresh materials (roots and rhizomes) and plant residues (decomposed plant materials with identifiable organs and tissues) were separated by size. Mineral materials were generally identified as coarse silt-sized particles or larger. Smaller mineral particles were likely masked by organic fine material and could not be identified under the microscope at $100 \times$ magnification. Void spaces were not counted, because it was difficult to discern natural voids from artifacts due to the drying process and slide preparation. Point counts (300 per slide) were made along transects oriented parallel to the soil surface to quantify percent mineral, and fresh and decomposed organic soil materials based on size and decomposition on an area basis (Blazejewski et al. 2005).

Soil shear strength was measured adjacent to coring sites in May 2012 at JoCo and Blank Bank marshes to compare belowground structure (i.e., organic matter, biomass) with soil erosion resistance. Soil shear strength describes the resistance of a soil to shearing stresses derived from the cohesion and frictional resistance of soil constituents. We used a Geonor H-60 vane borer (Oslo, Norway) to measure shear strength at different soil depths (Turner et al. 2009). Profiles of soil shear strength were determined by measuring the soil shear stress required to force soil failure, in kilopascals, at 10 depths, beginning at a depth of $10 \mathrm{~cm}$ and in increments of $10 \mathrm{~cm}$ thereafter. The final depth measured in each profile was $100 \mathrm{~cm}$. Ten soil shear-strength profiles were carried out at each marsh. The replicates at each marsh were spaced about $30-50 \mathrm{~cm}$ apart, equally sampling the vegetated creek bank and adjacent high marsh.

\section{Archival qualities of salt marsh soil cores}

To reconstruct historic sediment accumulation rates, nitrogen isotope ratios, and percent soil nitrogen, three $50 \mathrm{~cm}$ deep, mid-marsh cores were collected with a Macaulay peat sampler (Jowsey 1966) from the JoCo Marsh in October 2008. We conducted the historic reconstruction at the JoCo Marsh, because it was the most stable marsh at the time of sampling and representative of the larger Jamaica Bay marsh island system. We generalized the historic reconstruction from the stable marsh site to the larger marsh system.

Sectioning resulted in resolution of $3 \mathrm{~cm}$ to a depth of $30 \mathrm{~cm}$, and $5 \mathrm{~cm}$ from $30-50 \mathrm{~cm}$ of depth. Dry samples were sieved to remove macro-organic matter, and introduced into either a Ge well detector (GL20203, Canberra, Meridian, Connecticut, USA; $150 \mathrm{~cm}^{3}$ ) or pure Ge planar detector (Canberra 2020) for measurement of ${ }^{210} \mathrm{~Pb},{ }^{226} \mathrm{Ra}$, and ${ }^{137} \mathrm{Cs}$. Counting efficiencies for ${ }^{210} \mathrm{~Pb}$, ${ }^{226} \mathrm{Ra}\left({ }^{214} \mathrm{~Pb}\right)$, and ${ }^{137} \mathrm{Cs}$ were obtained by counting sediment standards obtained from the National Institute of Standards and Technology. For each core, ${ }^{210} \mathrm{~Pb}$ excess (xs) activities were calculated by subtracting the measured average ${ }^{226} \mathrm{Ra}$ activity from the total ${ }^{210} \mathrm{~Pb}$ activity: ${ }^{210} \mathrm{~Pb}_{\mathrm{xs}}=$ total ${ }^{210} \mathrm{~Pb}-{ }^{226} \mathrm{Ra}\left({ }^{214} \mathrm{~Pb}\right)$ activity. Sediment accumulation rates and chronologies were generated using a linear regression of the natural log of excess ${ }^{210} \mathrm{~Pb}$ activity vs. depth, assuming a constant rate of ${ }^{210} \mathrm{~Pb}$ supply (e.g., Appleby and Oldfield 1978, Krishnaswami et al. 1980, Cochran et al. 1992). The mean ( $n=3$ cores) sediment accumulation rate was used to date the marsh soil and examine for temporal patterns in nitrogen isotope ratios and percent soil nitrogen with depth. The ${ }^{210} \mathrm{~Pb}_{\mathrm{xs}}$-derived sediment accumulation rates were compared to depth profiles of ${ }^{137}$ Cs (mainly a product of atmospheric weapons testing), by assuming that ${ }^{137} \mathrm{Cs}$ supply to the environment began in 1954, with a peak in 1963. The depth of the measured ${ }^{137} \mathrm{Cs}$ peak, where discernible, provides a time-stratigraphic marker that serves as an independent check on the calculated sediment accumulation rate.

The stable nitrogen isotopic composition and percent nitrogen of historic marsh sediments to a depth of $50 \mathrm{~cm}$ were determined by continuous flow isotope ratio mass spectrometry (CF-IRMS) employing a Carlo-Erba NA 1500 Series II Elemental Analyzer (CE Elantech, Lakewood, New Jersey, USA) interfaced to a Micromass Optima Mass Spectrometer (Elementar Americas, Mt. Laurel, New Jersey, USA) using standard methods (McClelland et al. 1997, McKinney et al. 2001). The nitrogen isotope ratio of the soil was expressed as a part per thousand (per mil) difference from the composition of a recognized reference material, which by convention is $\mathrm{N}_{2}$ in air (Mariotti 1983). All samples were analyzed in duplicate with a typical difference of about $0.1 \%$.

\section{Statistics}

Two-way ANOVAs with site (Black Bank, JoCo) and location (creek, mid, high) as main effects were used to analyze belowground responses (i.e., roots, rhizomes, and peat). Soil carbon dioxide emission data were logtransformed prior to applying a two-way ANOVA examining for the main effects of year and site. A three-way ANOVA was used to examine organic matter over depth in marsh cores, with soil depth, site, and location as the main effects. Two-tailed $t$ tests were used to test for differences in the depth-averaged means of the soil percent carbon, nitrogen, phosphorus, and the N:P 

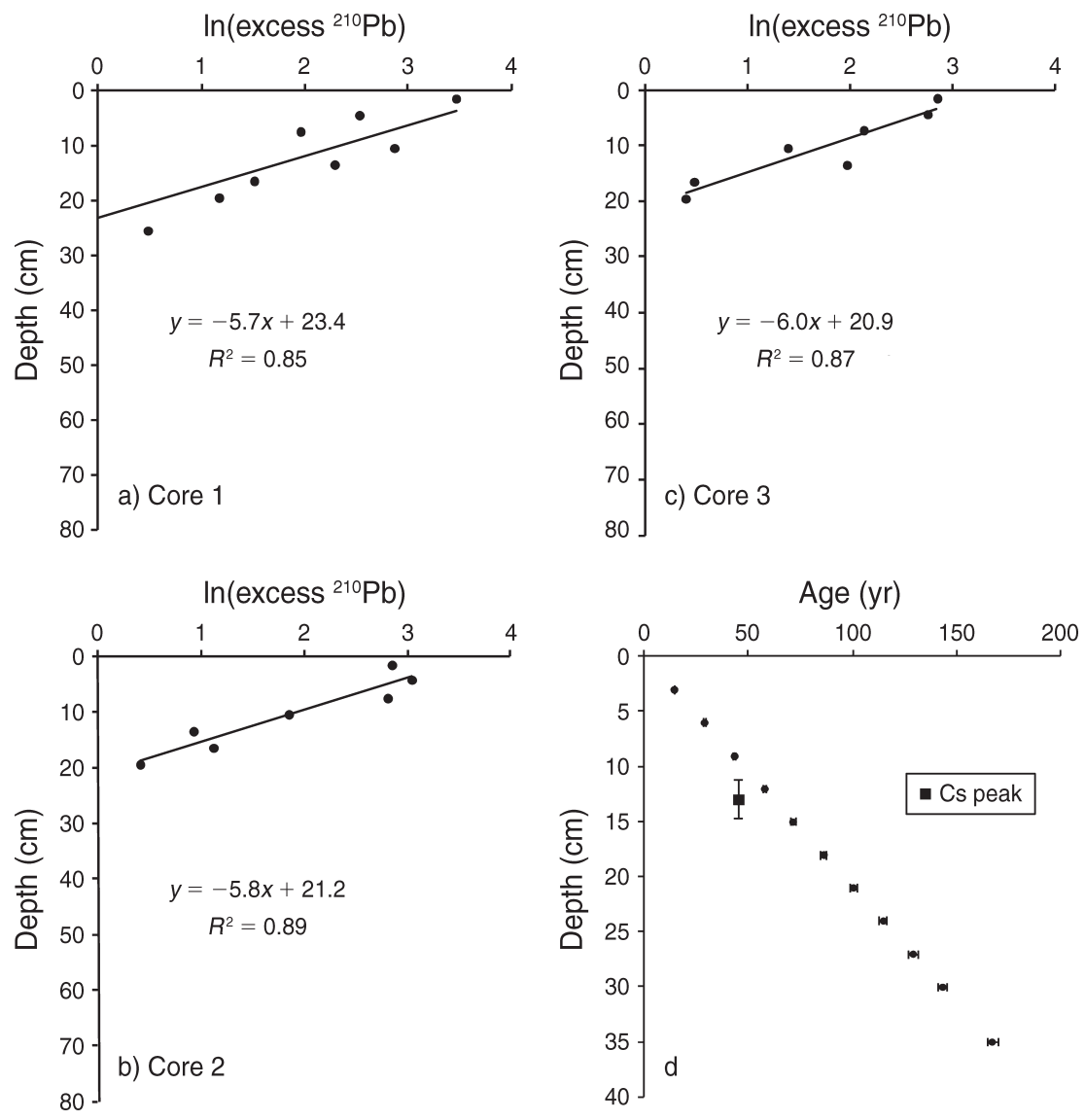

FIG. 2. (a-c) Excess ${ }^{210} \mathrm{~Pb}$ activity (measured as disintigrations $\left.\cdot \mathrm{min}^{-1} \cdot \mathrm{g}^{-1}\right)$ vs. depth for the JoCo marsh cores $(n=3)$ fit with a linear regression. (d) Age (mean $\pm \mathrm{SE}$ ) vs. depth chronology based on the ${ }^{210} \mathrm{~Pb}$ sediment accumulation rates. The peak ${ }^{137} \mathrm{Cs}(1963$, 45 years before sampling year 2008) depth was plotted with the chronology. Sediment accumulation rates were generated assuming a constant rate of ${ }^{210} \mathrm{~Pb}$ supply.

molar ratios and C:N molar ratios between sites. A twoway ANOVA was used to examine soil shear strength over depth, with soil depth and site as the main effects. Regression analyses were used to examine for relationships between the nitrogen isotope ratios of the soils and the ln-transformed human population, and to determine the rates of accretion and elevation change, and ANCOVA to test for differences in the slopes of the accretion and elevation relationships. Means are reported with standard errors. The probability for significance was $P<0.05$ for all statistical analyses.

\section{RESULTS}

\section{Historic reconstruction of marsh soils}

The three JoCo marsh cores all displayed an exponential decrease in excess ${ }^{210} \mathrm{~Pb}$ (Fig. 2). The mean sediment accumulation rate for the three cores, based on analysis of the upper $20-30 \mathrm{~cm}$, was $0.21 \pm 0.003 \mathrm{~cm} / \mathrm{yr}$. The ${ }^{210} \mathrm{~Pb}$-derived sediment accumulation rates were used to develop a chronology estimating the age of the marsh soils with depth (Fig. 2d). The mean depth of ${ }^{137} \mathrm{Cs}$ peak was located below the chronology at about
60 years, close to the 1950s (Fig. 2d). Decomposition in the surface marsh soils, downward diffusion, and/or mixing of ${ }^{137} \mathrm{Cs}$ might explain the downward shift of the ${ }^{137} \mathrm{Cs}$ peak in the cores (Turner et al. 2006, Mudd et al. 2009).

Our interpretation of the census data and historic records is that the watershed and surrounding counties of Jamaica Bay were sparsely populated prior to the 1850s, with an average population of about 2900 people in the 1700s and 14500 in the early 1800s, composed of mostly farmers. However, during the U.S. Revolutionary War (1775-1783), about 40000 combined British and U.S. troops occupied this area. The watershed population began to rise steeply in the 1850 s, when about 79000 new immigrants settled in the watershed, and continued to rise until the 1970s. There was a decline of about 250000 people in the 1980s. In the year 2000 , the watershed was highly populated with 2.25 million people (Fig. 3a). The nitrogen isotope ratios doubled across all three marsh cores from a mean of $1.7 \%$ in the early 1770 s to a mean of $3.4 \%$ in the 1790 s (Fig. 3b). There was a rise in the soil percent nitrogen and the nitrogen isotope ratios beginning in the mid 

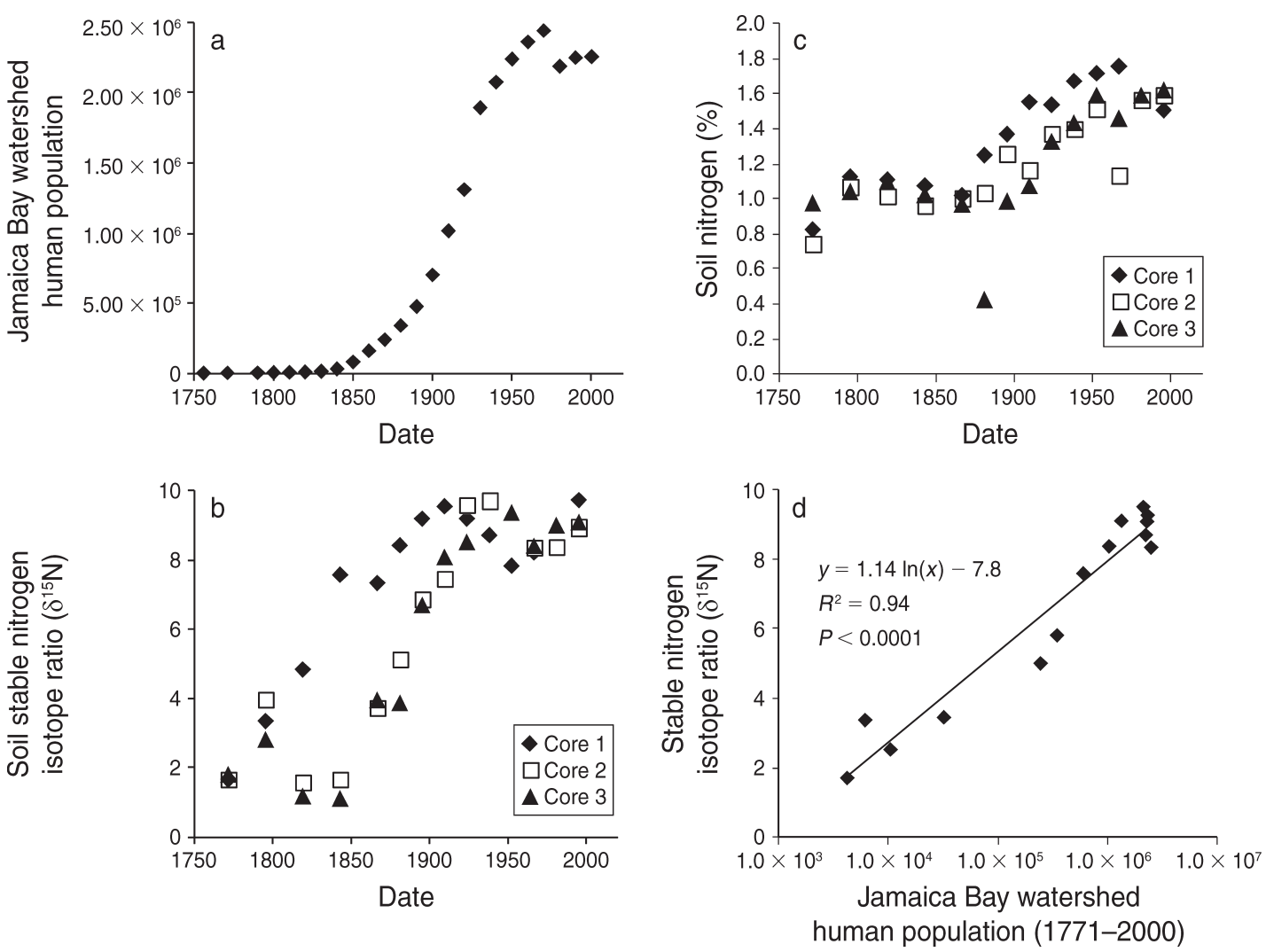

FIG. 3. Temporal relationships in JoCo marsh soils with depth of (a) population, (b) nitrogen isotope ratios, (c) soil nitrogen, and (d) relationship of human population and the mean nitrogen isotope ratios from 1770 to 2000. Population estimates were based on historic records (Greene and Harrington 1932) and census data (Forstall 1996, U.S. Census 2000).

1800s that mirrored the rise in human population during this same time period (Fig. 3b, c). From the early 1800 s to the 1940s, the mean nitrogen isotope ratios of the marsh cores rose linearly from $2.5 \%$ to a peak of $9.5 \%$. From approximately 1960 to 1980 , there was a decline from the $1940 \mathrm{~s}$ peak of $9.5 \%$ to a mean of $8.5 \%$ among cores (Fig. 3b). There was a highly significant positive regression relationship $\left(R^{2}=0.94, P<0.0001\right)$ between the nitrogen isotope ratios and the ln-transformed human population in the Jamaica Bay watershed (Fig. 3d).

\section{Description of the marsh soil structure among disappearing, restored, and stable marshes}

Macromorphological observations of the low marsh vegetated cores collected in 2006 among the four Jamaica Bay sites showed three distinct soil types. The restored Big Egg site was dominated by sand-textured C horizons (Table 1). The development of an A horizon was limited to the upper $3 \mathrm{~cm}$ of the profile (Table 1). Adequate time had not elapsed for an organic horizon to form on top of recently deposited mineral soil. Soil in the JoCo core had a $9 \mathrm{~cm}$ mineral A horizon of silt loam texture over the underlying mucky peat $(\mathrm{Oe})$ and muck (Oa). The fine nature and silt loam texture of the A horizon suggested a slow depositional process. This layer was likely the result of considerable sediment input from tidal creek flooding over the last three or four decades. The Black Bank and Big Egg cores were similar in morphologies with a series of $\mathrm{Oa}$ (muck) horizons dominated by finely dispersed soil organic matter (Table 1). These horizons were typical of salt marsh peat soils that were in very low energy environments. Within all of the soils at least some horizons smelled slightly to strongly of hydrogen sulfide, which was indicative of typical salt marsh soils. With the exception of the restored site at Big Egg, the mineral materials in the soil thin sections composed $3 \%$ or less of the marsh materials on an area basis (Table 1). Creek sediment was placed at the restored Big Egg site in 2003 to increase the elevation during the restoration and thus the high mineral content (78\%), sandy texture, and domination by $\mathrm{Cg}$ horizons (Table 1). At the restored Big Egg marsh, signs of marsh soil development were evident with $10 \%$ fresh soil organic materials in the upper $10 \mathrm{~cm}$ and development of a thin A horizon (3 cm thick, Table 1). The thin sections of the natural marshes had similar amounts of decomposed organic soil materials (about 81\%), while the restored site had only $12 \%$ (Table 1 ).

There were apparent site differences in the CT image profiles of coarse roots, rhizomes, and peat with depth, with the greatest volume of coarse roots and rhizomes in 
TABLE 1. Representative morphological descriptions of the Jamaica Bay soils.

\begin{tabular}{|c|c|c|c|c|c|}
\hline \multirow[b]{3}{*}{ Horizon } & \multirow{2}{*}{\multicolumn{2}{|c|}{$\begin{array}{c}\text { Macromorphological } \\
\text { descriptions }\end{array}$}} & \multicolumn{3}{|c|}{$\begin{array}{l}\text { Micromorphological descriptions } \\
\text { (upper } 10 \mathrm{~cm} \text { ) }\end{array}$} \\
\hline & & & \multirow{2}{*}{$\begin{array}{l}\text { Decomposed } \\
\text { materials }(\%)\end{array}$} & \multirow{2}{*}{$\begin{array}{c}\text { Fresh } \\
\text { materials }(\%)\end{array}$} & \multirow{2}{*}{$\begin{array}{l}\text { Mineral } \\
(\%)\end{array}$} \\
\hline & Depth $(\mathrm{cm})$ & Texture & & & \\
\hline JoCo Marsh & & & 78 & 20 & 2 \\
\hline A & $0-9$ & mucky silt loam & & & \\
\hline $\mathrm{Oe}$ & $9-22$ & mucky peat & & & \\
\hline $\mathrm{Oa}$ & $22-25+$ & muck & & & \\
\hline Black Bank Marsh & & & 83 & 15 & 2 \\
\hline Oal & $0-1$ & muck & & & \\
\hline $\mathrm{Oa} 2$ & $1-12$ & muck & & & \\
\hline $\mathrm{Oa} 3$ & $12-19$ & muck & & & \\
\hline $\mathrm{Oa} 4$ & $19-25+$ & muck & & & \\
\hline Big Egg Marsh & & & 83 & 14 & 3 \\
\hline Oa1 & $0-8$ & muck & & & \\
\hline $\mathrm{Oa} 2$ & $8-16$ & muck & & & \\
\hline $\mathrm{Oa} 3$ & $16-25+$ & muck & & & \\
\hline Restored Big Egg Marsh & & & 12 & 10 & 78 \\
\hline A & $0-3$ & sand & & & \\
\hline $\mathrm{Cg} 1$ & $3-11$ & sand & & & \\
\hline $\mathrm{Cg} 2$ & $11-15$ & sand & & & \\
\hline $\mathrm{Cg} 3$ & $15-22+$ & sand & & & \\
\hline
\end{tabular}

Notes: Cores were generally collected to $25 \mathrm{~cm}$. Percentages of mineral and organic materials (decomposed and fresh) in the upper $10 \mathrm{~cm}$ of the salt marsh soils at JoCo, Black Bank, Big Egg, and Restored Big Egg marshes was determined using micromorphological methods. The micromorphological point count data are on a percentage of area basis. Void spaces were not counted because it is difficult to discern natural voids from artifacts due to the drying process and slide preparation. Percentage of mineral materials may be underestimated, because at $100 \times$ magnification mineral grains smaller than $20 \mu \mathrm{m}$ are not distinguishable.

the JoCo marsh soils (Fig. 4a; see Plate 1), with JoCo $(18.4 \%)>$ Black Bank $(14.5 \%)>\operatorname{Big} \operatorname{Egg}(7.7 \%)>$ restored Big Egg (2.4\%; Table 2). However, the magnitude of the root and rhizome volume at the $3 \mathrm{~cm}$ depth in the restored Big Egg site was greater than the volume at the Big Egg marsh and similar to the volume at the Black Bank marsh (Fig. 4a). The volume of the peat showed the opposite pattern as the volume of the roots in the natural marshes (i.e., excluding the restored site) with the greatest volume of peat at the Big Egg marsh (Fig. 4b), and the peat volume at the Big Egg marsh $(84.7 \%)$ greater than at Black Bank $(75.6 \%)$, which was greater than at JoCo $(69.3 \%)$ and greater than at the restored Big Egg site (3.8\%; Table 2). The Black Bank and Big Egg marsh cores were dominated by finely dispersed organic matter (muck) with high waterholding capacity, which was reflected in their high peat volumes. The highest percentages of gas in the marsh soils were measured at the Big Egg marsh, with Big Egg $(1.2 \%)>$ Black Bank $(0.9 \%)>$ JoCo $(0.5 \%)>$ restored Big Egg (0.1\%; Table 2).

\section{Comparative study between the stable JoCo and deteriorating Black Bank marshes}

Based on our SET data collection, the JoCo marsh rate of elevation change was $5.1 \pm 0.4 \mathrm{~mm} / \mathrm{yr}\left(R^{2}=0.94\right.$, $P<0.0001)$ and that of Black Bank, $4.9 \pm 0.2 \mathrm{~mm} / \mathrm{yr}$ $\left(R^{2}=0.98, P<0.0001\right)$. The average accretion rates
(JoCo, $4.4 \pm 0.5 \mathrm{~mm} / \mathrm{yr}, R^{2}=0.89, P<0.0001$; Black Bank, $\left.4.4 \pm 0.3 \mathrm{~mm} / \mathrm{yr}, R^{2}=0.93, P<0.0001\right)$ at both sites were less than, but similar in magnitude to the rate of elevation change. There was no significant difference between the accretion rate and the rate of elevation change at each site, and there were no significant differences in the rates of elevation change or accretion rates between sites.

There was no significant difference in plant cover between sites. The quadrats were dominated by $S$. alterniflora, which averaged $95.1 \% \pm 1.3 \%(n=18)$. The stem lengths were significantly longer at the Black Bank site (creek $144.4 \pm 3.9 \mathrm{~cm}$, mid $121.3 \pm 6.9 \mathrm{~cm}$, high $101.4 \pm 3.4 \mathrm{~cm}$ ) compared to the JoCo site (creek 100.0 $\pm 2.6 \mathrm{~cm}$, mid $65.4 \pm 3.2 \mathrm{~cm}$, high $50.3 \pm 3.0 \mathrm{~cm}$ ), and significantly decreased with distance from the creekbank to the high-marsh locations (two-way ANOVA, site effect $P<0.0001$, location effect $P<0.0001$, nonsignificant interaction). The dry biomass of roots and rhizomes among locations was significantly greater at the JoCo site (creek $7144 \pm 273 \mathrm{~g}$ dry mass $/ \mathrm{m}^{2}$, mid $10936 \pm 1052 \mathrm{~g}$ dry mass $/ \mathrm{m}^{2}$, high $12522 \pm 321 \mathrm{~g}$ dry mass $/ \mathrm{m}^{2}$ ) than at the Black Bank site (creek $7302 \pm 572$ g dry mass $/ \mathrm{m}^{2}$, mid $8488 \pm 428 \mathrm{~g}$ dry mass $/ \mathrm{m}^{2}$, high $9826 \pm 215 \mathrm{~g}$ dry mass $/ \mathrm{m}^{2}$; two-way ANOVA, site effect $P=0.003$, location effect $P<0.0001$, interaction $P<$ 0.05 ). Both marsh sites showed a pattern of increasing belowground biomass from the creek-bank to the high- 


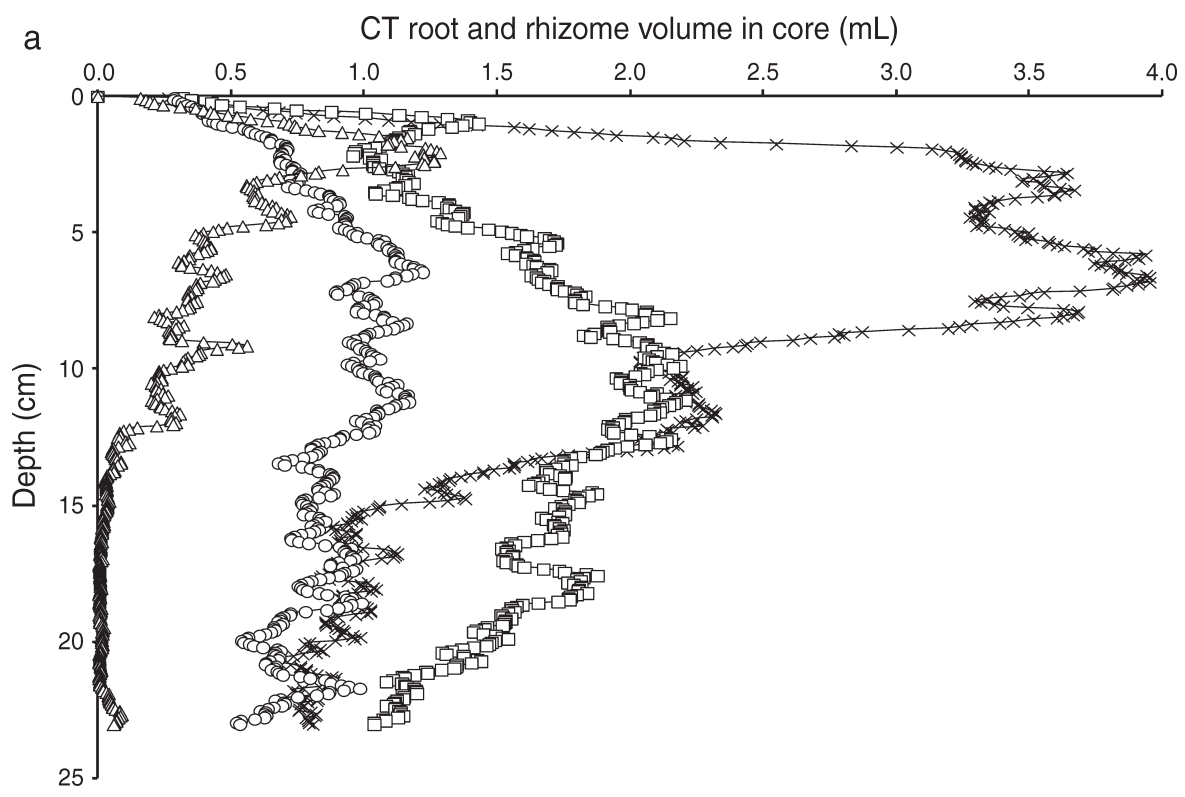

b

CT peat volume in core $(\mathrm{mL})$

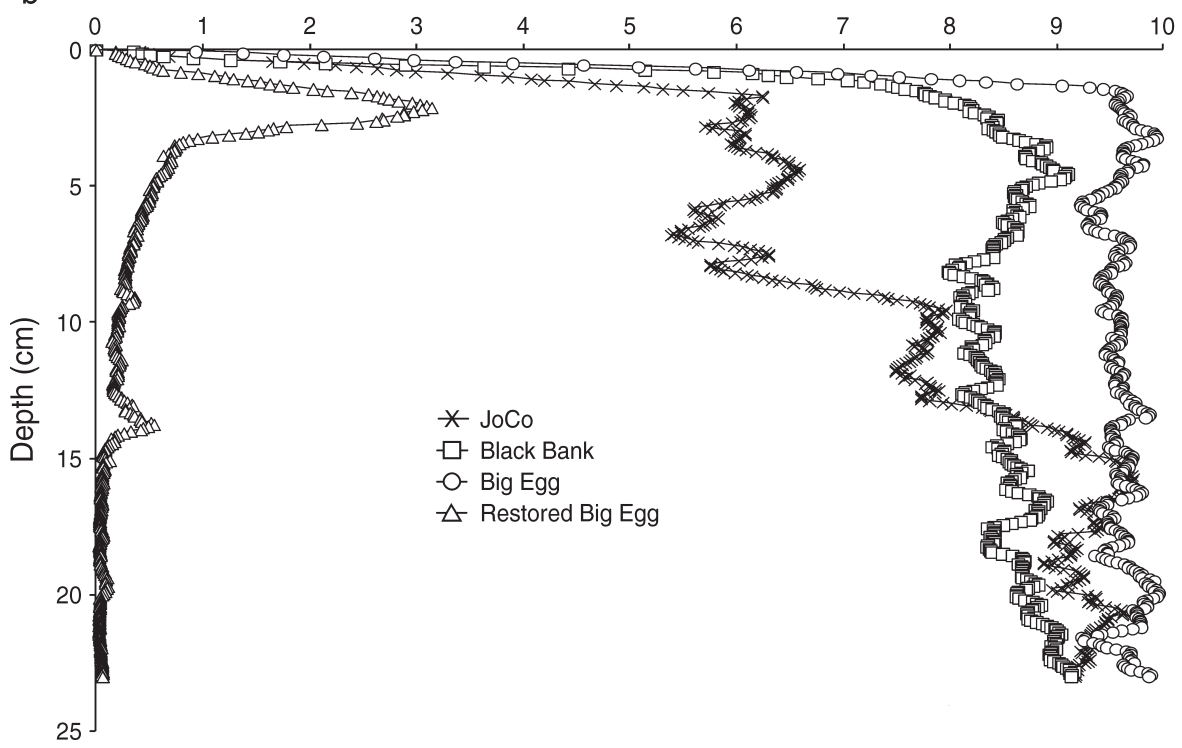

FIG. 4. Profiles of volume with depth of (a) coarse root and rhizomes and (b) peat for JoCo, Black Bank, Big Egg, and Restored Big Egg soils collected from the low marsh. Volumes were determined from one core per site with computer-aided tomography (CT) imaging and reported every $0.625 \mathrm{~mm}$.

TABLE 2. Soil components determined by computer-aided tomography (CT) imaging and reported as percentage of volume in Jamaica Bay marsh cores, one per site.

\begin{tabular}{lcccccccc}
\hline \hline \multicolumn{1}{c}{ Marsh } & $\begin{array}{c}\text { Elevation } \\
(\mathrm{cm})\end{array}$ & Gas (\%) & $\begin{array}{c}\text { Roots and } \\
\text { rhizomes (\%) }\end{array}$ & Water (\%) & Peat (\%) & Part (\%) & Sand (\%) & $\begin{array}{c}\text { Rock and } \\
\text { shell fragments (\%) }\end{array}$ \\
\hline JoCo & +8 & 0.5 & 18.4 & 11.6 & 69.3 & 0.2 & 0.0 & 0.0 \\
Black Bank & -17 & 0.9 & 14.5 & 7.0 & 75.6 & 1.9 & 0.0 & 0.0 \\
Big Egg & -55 & 1.2 & 7.7 & 6.0 & 84.7 & 0.2 & 0.1 & 0.0 \\
Big Egg (Restored) & -3 & 0.1 & 2.4 & 0.5 & 3.8 & 8.8 & 79.6 & 4.9 \\
\hline
\end{tabular}

Notes: Vegetated cores were collected in the low marsh. Marsh elevation is reported relative to mean high water (MHW). Part stands for particles finer than sand, such as silts and clays. 
marsh locations, with the greatest belowground biomass in the high marsh. The creek-bank dry belowground biomass was similar at the JoCo and Black Bank sites, but the belowground biomasses at the mid- and highmarsh locations were greater at the JoCo site than at the Black Bank site. The above- to belowground mean dry biomass ratio was significantly greater at the Black Bank site (creek $0.46 \pm 0.06$, mid $0.25 \pm 0.08$, high $0.13 \pm$ 0.03 ) compared to the JoCo site (creek $0.16 \pm 0.04$, mid $0.06 \pm 0.01$, high $0.04 \pm 0.003$ ), and significantly greater at the creek-bank locations compared with the midmarsh and high-interior-marsh locations (two-way ANOVA, site effect $P=0.0002$, location effect $P=$ 0.0009 , nonsignificant interaction).

Similar to the dry belowground biomass, the abundances of the coarse roots and the abundances of the rhizomes at shallow depths showed significant main effects and interactions (two-way ANOVAs, site effects $P<0.0001$, location effects $P<0.0001$, interactions $P$ $<0.01$ ). The abundances (number $/ \mathrm{m}^{2}$ ) of coarse roots and rhizomes at shallow depths in the JoCo marsh cores were lowest at the creek-bank locations (coarse roots $7648 \pm 1095$; rhizomes $4224 \pm 358$ ), but similar in magnitude at the mid-marsh (coarse roots $18199 \pm 572$; rhizomes $9494 \pm 196$ ) and high-marsh locations (coarse roots $16781 \pm 1172$; rhizomes $9340 \pm 918)$. In contrast, the abundances (number $/ \mathrm{m}^{2}$ ) of the coarse roots and rhizomes at shallow depths at the Black Bank site were low at both the creek-bank (coarse roots $5800 \pm 1071$; rhizomes $3750 \pm 621$ ) and high-marsh locations (coarse roots $6346 \pm 1808$; rhizomes $3124 \pm 882$ ), but greater at the mid-marsh locations (coarse roots $10576 \pm 692$; rhizomes $7243 \pm 382$ ). The abundances (number $/ \mathrm{m}^{2}$ ) of the rhizomes at depths of $10-20 \mathrm{~cm}$ were significantly greater at both sites in the high-marsh locations (JoCo $10072 \pm 69$; Black Bank $8171 \pm 683)$, compared to the mid- (JoCo $5344 \pm 280$; Black Bank $4508 \pm 228$ ) and creek-bank locations (JoCo $5658 \pm 243$; Black Bank $5468 \pm 174)$ (two-way ANOVA, site effect $P<0.004$, location effect $P<0.0001$, nonsignificant interaction). The abundances of the coarse roots at depths of 10-20 $\mathrm{cm}$ were of similar magnitude as the abundances at shallow depths, and the two-way ANOVA revealed significant site $(\mathrm{JoCo}>$ Black Bank, $P<0.0001)$, location $(P<0.0001)$, and site-by-location interaction $(P=0.001)$.

There were significant and noticeable differences in the diameters of the rhizomes between sites and among locations (two-way ANOVAs, shallow depth, site effect $P=0.0014$, location effect $P=0.014$, site by location $P=$ $0.013 ; 10-20 \mathrm{~cm}$ depth, site effect $P<0.0001$, location effect $P=0.008$, site by location $P=0.0005$ ). The average diameter of the rhizomes across locations at the JoCo site was $3.38 \pm 0.102 \mathrm{~mm}$ at shallow depths and $3.40 \pm 0.210 \mathrm{~mm}$ at the $10-20 \mathrm{~cm}$ depth compared to $3.75 \pm 0.211 \mathrm{~mm}$ and $3.85 \pm 0.111 \mathrm{~mm}$, respectively, at the Black Bank site. The greatest rhizome diameters were measured in the mid-marsh locations at shallow depths at Black Bank $(4.10 \pm 0.123 \mathrm{~mm})$.

In contrast, there were no significant differences in the diameters of the coarse roots between the JoCo and Black Bank sites, although the deep coarse roots had significantly greater diameters in the high-marsh interior locations (JoCo $1.39 \pm 0.003 \mathrm{~mm}$; Black Bank $1.38 \pm$ $0.006 \mathrm{~mm}$ ) compared with the mid-marsh (JoCo $1.36 \pm$ $0.006 \mathrm{~mm}$; Black Bank $1.35 \pm 0.003 \mathrm{~mm})$ and creekbank locations (JoCo $1.37 \pm 0.012 \mathrm{~mm}$; Black Bank 1.36 $\pm 0.002 \mathrm{~mm}$; two-way ANOVAs, shallow depth, site effect $P=0.067$, location effect $P=0.031$, site by location $P=0.002 ; 10-20 \mathrm{~cm}$ depth, site effect $P=0.16$, location effect $P=0.003$, site by location $P=0.96$ ).

The CT peat particle density of the Black Bank site was significantly greater than the $\mathrm{CT}$ peat particle density of the JoCo site in the mid-marsh (shallow depth, JoCo $1.057 \pm 0.002 \mathrm{~g} / \mathrm{mL}$, Black Bank $1.073 \pm$ $0.003 \mathrm{~g} / \mathrm{mL} ; 10-20 \mathrm{~cm}$ depth, JoCo $1.071 \pm 0.004 \mathrm{~g} / \mathrm{mL}$, Black Bank $1.085 \pm 0.002 \mathrm{~g} / \mathrm{mL}$ ) and high-marsh locations (shallow depth, JoCo $1.056 \pm 0.003 \mathrm{~g} / \mathrm{mL}$, Black Bank $1.075 \pm 0.001 \mathrm{~g} / \mathrm{mL} ; 10-20 \mathrm{~cm}$ depth, JoCo $1.061 \pm 0.003 \mathrm{~g} / \mathrm{mL}$, Black Bank $1.112 \pm 0.011 \mathrm{~g} / \mathrm{mL}$ ), however, the CT peat particle density of the JoCo site was greater than that of the Black Bank site in the creekbank locations (shallow depth, JoCo $1.114 \pm 0.004 \mathrm{~g} /$ $\mathrm{mL}$, Black Bank $1.110 \pm 0.003 \mathrm{~g} / \mathrm{mL} ; 10-20 \mathrm{~cm}$ depth, JoCo $1.122 \pm 0.0005 \mathrm{~g} / \mathrm{mL}$, Black Bank $1.108 \pm 0.005 \mathrm{~g} /$ $\mathrm{mL}$; two-way ANOVAs, shallow depth, site effect $P=$ 0.0009 , location effect $P<0.0001$, site by location $P=$ $0.0025 ; 10-20 \mathrm{~cm}$ depth, site effect $P=0.002$, location effect $P<0.0001$, site by location $P=0.0002$ ).

There were no significant differences in mean percent peat volume between the JoCo and Black Bank sites at either the shallow or 10-20 cm depths. The mid-marsh locations at the 10-20 cm depth (JoCo $77.1 \% \pm 0.8 \%$; Black Bank $71.0 \% \pm 1.5 \%$ ) had significantly greater mean percent peat volumes than the high-marsh locations (JoCo 65.6\% $\pm 2.2 \%$; Black Bank $33.9 \% \pm$ $15.1 \%)$. The JoCo site had a lower mean percent peat volume $(54.6 \% \pm 2.7 \%)$ than Black Bank $(63.5 \% \pm$ $9.0 \%$ ) at the creek-bank location at the $10-20 \mathrm{~cm}$ depth (two-way ANOVAs, shallow depth, site effect $P=0.17$, location effect $P=0.004$, site by location $P=0.003 ; 10$ $20 \mathrm{~cm}$ depth, site effect $P=0.14$, location effect $P=0.02$, site by location $P=0.05$ ). Also, there were no significant site differences in the mean peat wet mass between JoCo and Black Bank, but there were significant location effects at depth (two-way ANOVAs, shallow depth, site effect $P=0.07$, location effect $P=0.17$, site by location $P=0.002 ; 10-20 \mathrm{~cm}$ depth, site effect $P=0.16$, location effect $P=0.02$, site by location $P=0.06$ ). Averaged across both sites at the $10-20 \mathrm{~cm}$ depth, the mean peat wet mass was greatest in the mid-marsh locations, and the mean peat wet mass in the mid-marsh locations (77.2 $\mathrm{kg} / \mathrm{m}^{2}$ ) was significantly greater than the mean peat wet mass of the high-marsh locations $\left(51.7 \mathrm{~kg} / \mathrm{m}^{2}\right)$. At the Black Bank site at the 10-20 cm depth, the high-marsh 
interior location had the lowest mean peat wet mass $\left(35.9 \pm 15.7 \mathrm{~kg} / \mathrm{m}^{2}\right)$ and percent peat volume $(33.9 \% \pm$ $15.1 \%)$, compared with peat at the mid-marsh location (mass $74.5 \pm 1.5 \mathrm{~kg} / \mathrm{m}^{2}$, volume $71.0 \% \pm 1.5 \%$ ) and creek bank (mass $68.0 \pm 9.5 \mathrm{~kg} / \mathrm{m}^{2}$, volume $63.5 \% \pm$ $9.0 \%)$.

Comparisons of the mean profiles of soil percent organic matter showed significant site $(P<0.0001)$ and location $(P<0.0001)$ effects, significant first order interactions of site by depth $(P<0.0001)$, location by depth $(P=0.025)$, and location by site $(P<0.0001)$ and a nonsignificant second-order interaction (three-way ANOVA; Fig. 5a). The profiles of percent organic matter at the JoCo and Black Bank sites were similar at the creek-bank locations. The mean percent organic matter was lowest at the creek-bank locations compared with the mid- and high-marsh locations (Fig. 5a). In the high-marsh locations, there were large differences in the profiles of the percent organic matter over depth between the sites. The mean percent organic matter at the Black Bank site ranged from $59.1 \% \pm 5.7 \%$ at the soil surface to $4.0 \% \pm 3.4 \%$ at $21 \mathrm{~cm}$ depth in the high marsh, while the mean percent organic matter at the JoCo site ranged from $61.4 \% \pm 4.5 \%$ at the soil surface to $52.2 \% \pm 0.7 \%$ at $21 \mathrm{~cm}$ depth in the high marsh (Fig. $5 a)$. Generally, the means of the percent organic matter in the Black Bank and JoCo cores at the mid- and highmarsh locations were similar in magnitude at the soil surface, but at depths greater than $10 \mathrm{~cm}$ the Black Bank percent organic matter was lower than the JoCo percent organic matter (Fig. 5a). Soil shear strength was significantly greater at the JoCo site than at the Black Bank site (two-way ANOVA, site effect $P=0.004$, nonsignificant site by depth interaction) and the differences in shear strength between sites were largest at the 30-50 cm depths (Fig. 5b).

The depth-averaged $(0-21 \mathrm{~cm})$ percent phosphorus (JoCo $0.084 \% \pm 0.002 \%$, Black Bank $0.074 \% \pm$ $0.001 \%$ ), percent nitrogen (JoCo $1.60 \% \pm 0.08 \%$, Black Bank $1.12 \% \pm 0.05 \%$ ), percent carbon (JoCo $24.8 \% \pm$ $1.02 \%$, Black Bank $16.1 \% \pm 0.98 \%$ ), and the N:P molar ratios (JoCo $44 \pm 3$, Black Bank $31 \pm 1)$ at the midmarsh locations were significantly $(P<0.05)$ greater at the JoCo Marsh than at Black Bank. The soil bulk density was significantly lower at the JoCo Marsh (0.14 $\pm 0.002 \mathrm{~g} / \mathrm{mL})$ than Black Bank $(0.27 \pm 0.023 \mathrm{~g} / \mathrm{mL})$. There was no significant difference between the C:N molar ratios (JoCo $18 \pm 1$, Black Bank $19 \pm 2$ ) between the sites.

Carbon dioxide emission rates at the creek-bank locations were significantly greater at the Black Bank site than at the JoCo site in 2006 and 2007, with greater rates at both sites in 2007 (two-way ANOVA on the logtransformed creek-bank data, site effect $P=0.006$, year effect $P<0.05$, nonsignificant interaction; Fig. 6). We measured significantly greater rates in the high-marsh locations $\left(5.30 \pm 0.63 \mu \mathrm{mol} \mathrm{CO}_{2} \cdot \mathrm{m}^{-2} \cdot \mathrm{s}^{-1}\right)$ than the creek-bank locations $\left(3.40 \pm 0.51 \mu \mathrm{mol} \mathrm{CO} \cdot \mathrm{m}^{-2} \cdot \mathrm{s}^{-1}\right)$
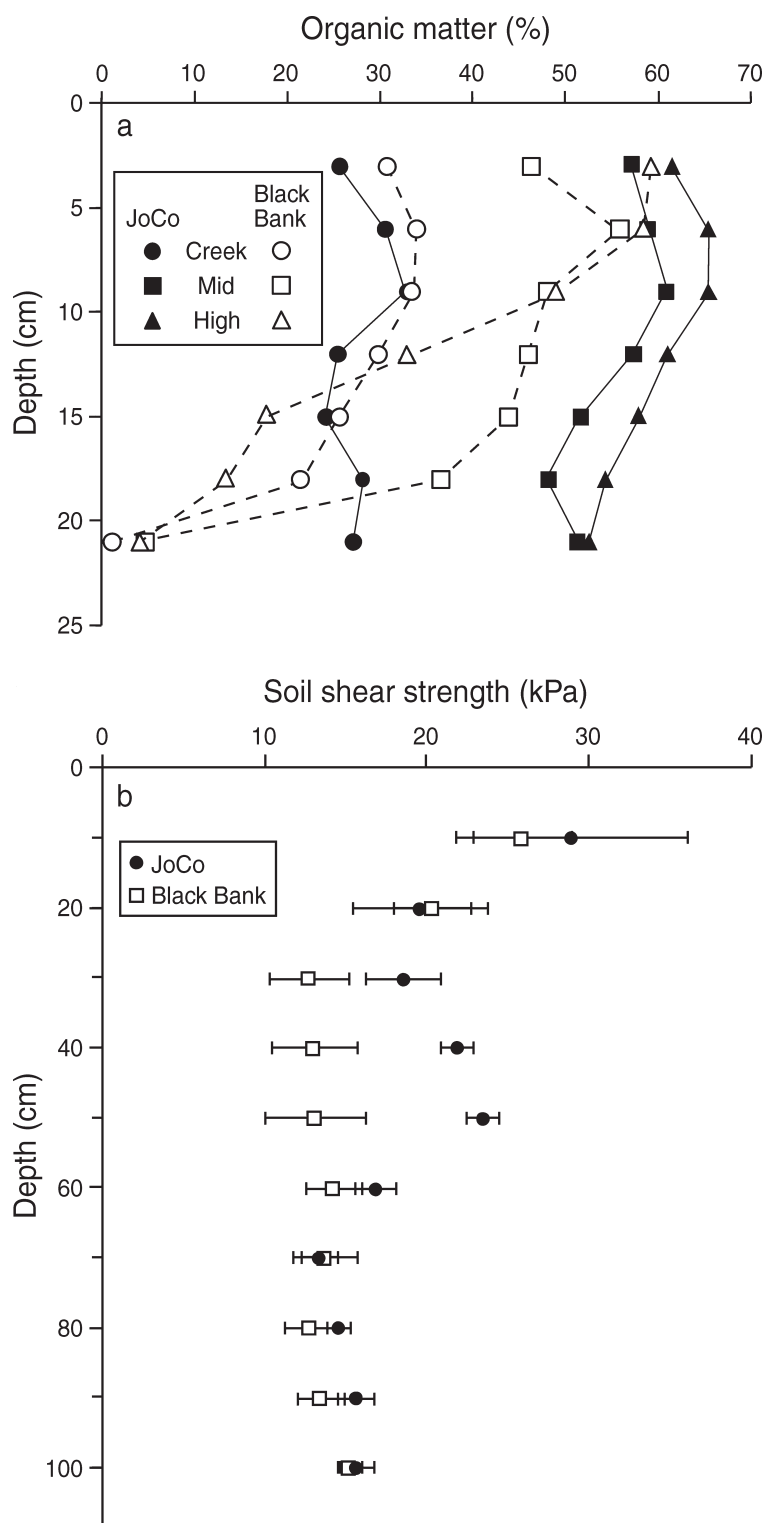

FIG. 5. Profiles over depth of (a) soil organic matter (mean; $n=3$ ) determined with dry samples after ashing and reported every $3 \mathrm{~cm}$ for the creek bank, mid marsh, and high marsh, and (b) soil shear strength (mean $\pm \mathrm{SE}$ ) at the JoCo and Black Bank marshes.

across sites in 2007 (Fig. 6). Carbon dioxide emission rates at the Black Bank site $(5.15 \pm 0.52 \mu \mathrm{mol}$ $\mathrm{CO}_{2} \cdot \mathrm{m}^{-2} \cdot \mathrm{s}^{-1}$ ) were significantly greater than at the JoCo site $\left(3.56 \pm 0.66 \mu \mathrm{mol} \mathrm{CO} \cdot \mathrm{m}^{-2} \cdot \mathrm{s}^{-1}\right)$ averaged across all three locations in 2007 (two-way ANOVA on the logtransformed data, site effect $P=0.02$, location effect $P=$ 0.03 , nonsignificant interaction; Fig. 6).

\section{DISCUSSION}

\section{Historic nutrient trends}

We successfully used radiometric dating, stable isotopes, and human census data to identify a cultural 


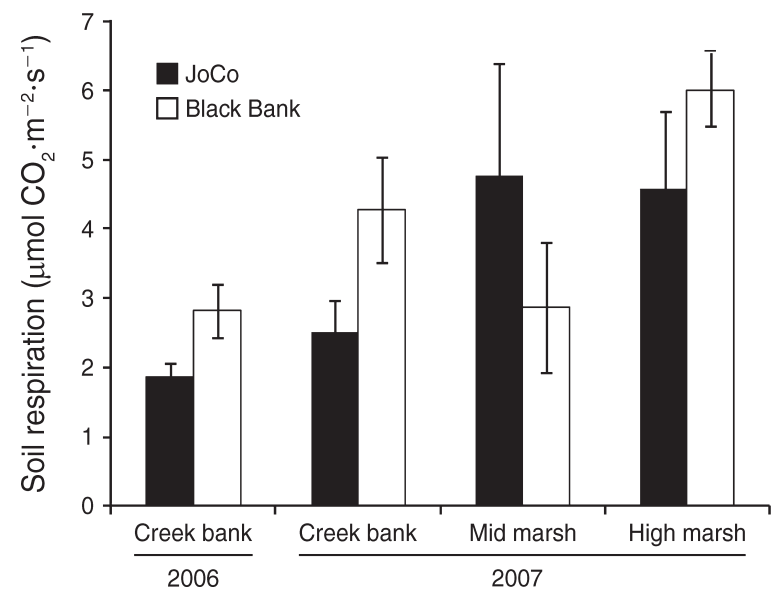

FIG. 6. Marsh soil carbon dioxide emission rates (mean and SE; $n=5$ replicates per site) for 2006 (creek bank) and 2007 (creek bank, mid marsh, high marsh) at Black Bank and JoCo marsh sites.

eutrophication signal (Fig. 3) in the Jamaica Bay marsh soils, which is similar to that described in other estuarine studies (Maren and Struck 1997, Struck et al. 2000, Castro et al. 2007). Doubling of the nitrogen isotope ratio between the 1770s and the 1790s (Fig. 3b) may be explained by the 40000 troops occupying this area during the U.S. Revolutionary War (McCullough 2005). Furthermore, the analyses suggest a rapid increase in wastewater nutrients beginning in the late 1840 s, and a tapering off in the 1930s when WWTPs were first installed (O'Shea and Brosnan 2000, Benotti et al. 2007). The Great Irish Potato Famine brought hundreds of thousands of immigrants to New York City in the late 1840s (Bayor and Meagher 1996), and after the U.S. Civil War (1861-1865) the rate of immigration from Europe grew steeply in NYC and the surrounding counties (Damon 1981). This large influx of European immigrants and the wastewater associated with human settlements and activities likely explain the rapid rise in the nitrogen isotope ratios from the 1850s to the 1940s (Fig. 3b). In the second half of the 20th century, the migration of people out of $\mathrm{NYC}$ and into more suburban areas of New Jersey and New York (Jackson 1985) may explain the dip in the population by about 250000 people in the 1980 s, and the reduction in the stable nitrogen ratio during the 1960s-1980s (Fig. 3a, b).

Our study suggests nutrient enrichment as a probable factor contributing to marsh loss in urban estuaries, such as Jamaica Bay, but it is certainly recognized that other factors also influence elevation dynamics of salt marshes. Conceptual models (e.g., Cahoon et al. 2009) identify the numerous processes and complex interactions that influence salt marsh vertical development, including frequency and duration of flooding, salinity, marsh surface sedimentation and erosion, above- and belowground plant biomass and decomposition, nutrient supply $(\mathrm{N}+\mathrm{P})$, and others. Given that Jamaica Bay is part of a densely urban watershed with a history of human-induced nitrogen loading (Fig. 3) estimated to have increased over 400 times since the pre-1900s (Benotti et al. 2007), it is reasonable to consider nutrient loading as an important factor. In addition to nitrogen loading, increases in phosphorus loading associated with WWTP inputs will stimulate microbial transformations, especially decomposition processes that may contribute to coastal salt marsh deterioration (Sundareshwar et al. 2003, Deegan et al. 2012). The percent nitrogen and percent phosphorus were on average about $56 \%$ and $22 \%$ greater, respectively, in salt marshes of Jamaica Bay than reported by Craft (2007) for northeastern Atlantic coast U.S. salt marshes. The enriched percent nitrogen and percent phosphorus in the Jamaica Bay salt marsh soil might be due to wastewater inputs of $\mathrm{N}$ and $\mathrm{P}$ over the last century. However, multi-parameter mesocosm and field manipulation studies, coupled with the continued development of process-driven models with dynamic feedbacks (e.g., Fagherazzi et al. 2012, Kirwan et al. 2010), will be essential to quantifying the relative importance of the many interacting factors that influence marsh loss. The information presented in this paper on marsh soil processes under a regime of high nutrient $(\mathrm{N}+\mathrm{P})$ loading should prove useful to future model development.

\section{Other anthropogenic impacts on the Jamaica Bay Estuary}

In addition to the stressor of increasing nutrient $(\mathrm{N}+$ P) loads, extensive dredging associated with navigational improvements and the construction of the J. F. Kennedy (initially named Idlewild) Airport, altered sediment delivery patterns and increased the tidal range within Jamaica Bay (Swanson and Wilson 2008). Prior to major reconfiguration for improved navigation, the tidal range throughout the bay varied by only $0.12 \mathrm{~m}$ in 1899 (Swanson and Wilson 2008). Physical alterations to the bay beginning in the early part of the 20th century resulted in an increase of the mean depth of the bay from $1 \mathrm{~m}$ to $5 \mathrm{~m}$ (Swanson et al. 1992). The J. F. Kennedy Airport was originally constructed in the 1940s on fill dredged from what is now known as Grassy Bay, the deepest part of the Jamaica Bay system (Swanson and Wilson 2008). The dredged areas in the bay may trap sediments that might have deposited on the marsh surface prior to development (Hartig et al. 2002). Urbanization of Brooklyn, Queens, and Nassau counties also may have diminished upland sediment sources and blocked some sediment overwash deposition (Hartig et al. 2002). These modifications to the Jamaica Bay Estuary could ultimately result in an increase in the frequency and duration of flooding of the marshes, which could contribute to erosional processes, fragmentation, and sulfide toxicity.

\section{Changes in the belowground marsh structure and marsh loss}

The soil N:P ratios, percent carbon, percent nitrogen, and percent phosphorus were greater at the JoCo site 

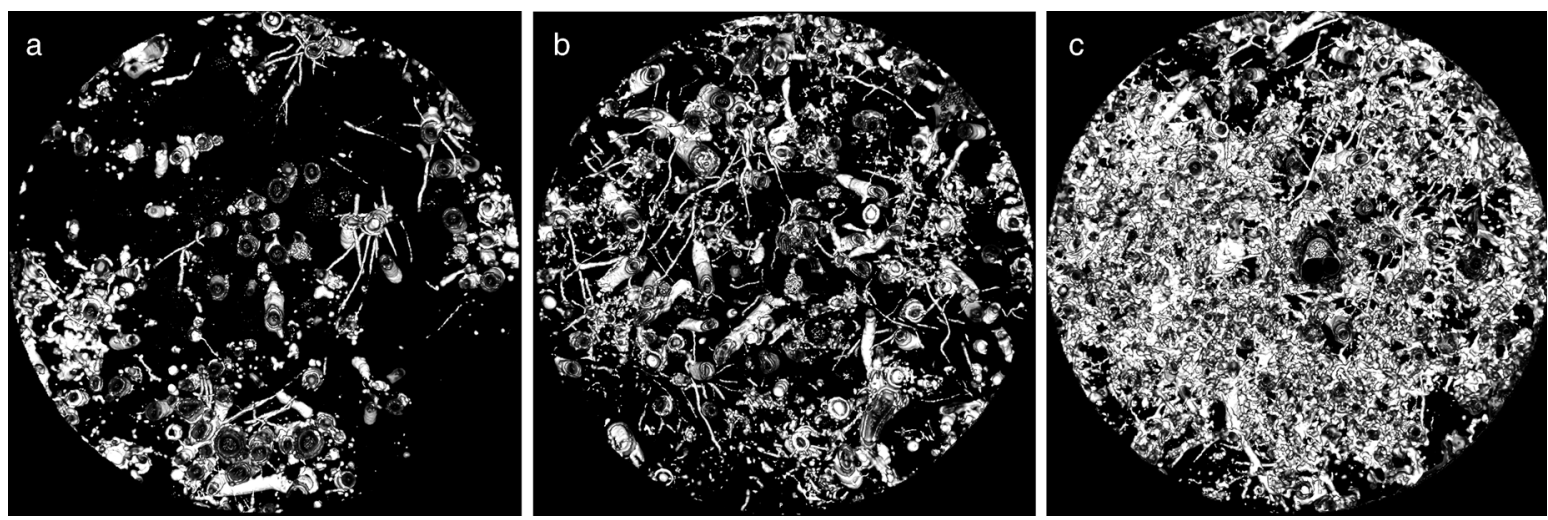

Plate 1. Cross sections of marsh cores showing roots and rhizomes at $10 \mathrm{~cm}$ depth sampled at the (a) deteriorating Big Egg, (b) deteriorating Black Bank, and (c) stable JoCo marshes in the Jamaican Bay Estuary. Computer-aided tomography was used to quantify coarse roots and rhizomes and create three dimensional images. Photo credit: E. Davey.

than Black Bank suggesting that the JoCo Marsh may have enhanced belowground productivity that adds carbon and organic nutrients to the soil and/or lower decomposition rates than Black Bank. We measured lower belowground mass and abundance of roots and rhizomes and elevated above/belowground ratios at the deteriorating Black Bank site. The above/belowground ratio is about threefold greater at the creek-bank location in the disappearing Black Bank site compared with the stable JoCo site. We also reported a decrease in the soil percent organic matter (Fig. 5a) and shear strength (Fig. 5b) at the Black Bank site compared to the stable JoCo site. Other investigators report similar findings in response to field-based fertilization experiments in northeastern U.S. salt marshes (e.g., Valiela et al. 1976, Turner et al. 2009, Turner 2011, Deegan et al. 2012), supporting the hypothesis that long-term pulsing of nutrient $(\mathrm{N}+\mathrm{P})$ inputs may be an important contributing factor to deterioration of Black Bank, Big Egg, and other marsh islands within Jamaica Bay.

At the creek bank of Plum Island (Massachusetts), where the marsh has undergone 9 years of a long-term fertilization experiment (Deegan et al. 2012), carbon dioxide emission rates $\left(4.02 \pm 0.60 \mu \mathrm{mol} \mathrm{CO} \mathrm{CO}_{2} \cdot \mathrm{m}^{-2} \cdot \mathrm{s}^{-1}, n\right.$ $=20$; C. Wigand, unpublished data) were similar in magnitude to the 2007 emission rates at the disappearing Black Bank creek-bank marsh $(4.28 \pm 0.75 \mu \mathrm{mol}$ $\mathrm{CO}_{2} \cdot \mathrm{m}^{-2} \cdot \mathrm{s}^{-1}$; Fig. 6). Likewise, the carbon dioxide emission rates at the stable JoCo creek bank $(2.52 \pm$ $0.46 \mu \mathrm{mol} \mathrm{CO} \mathrm{CO}_{2} \cdot \mathrm{m}^{-2} \cdot \mathrm{s}^{-1}$, Fig. 6) and the Plum Island control rates $\left(1.90 \pm 0.20 \mu \mathrm{mol} \quad \mathrm{CO}_{2} \cdot \mathrm{m}^{-2} \cdot \mathrm{s}^{-1} ; \mathrm{C}\right.$. Wigand, unpublished data) were of similar magnitude. In addition to the Plum Island experiment, increases in soil carbon dioxide emission rates have been reported in other marsh fertilization experiments (Morris and Bradley 1999, Anisfeld and Hill 2012) and in an observational study along a watershed nitrogen loading gradient (Wigand et al. 2009). The increased soil carbon dioxide emission rates measured in nutrient-enriched $(\mathrm{N}$ $+\mathrm{P})$ systems may be due to enhanced decomposition and microbial mineralization processes, which can cause losses in soil organic matter (Morris and Bradley 1999, Sundareshwar et al. 2003, Mack et al. 2004, Qualls and Richardson 2008). Deegan et al. 2012 reported increased microbial decomposition at the deteriorating, nutrientenriched Plum Island creek-bank site. Since the JoCo marsh does not show the elevated soil carbon dioxide emission rates, the JoCo marsh ( $8 \mathrm{~cm}$ above MHW) may not receive the same magnitude of nutrients or pulsing regime that the Black Bank marshes receive at the presently lower elevations (17 $\mathrm{cm}$ below MHW). Sources and types of sediment deposited on these two Jamaica Bay marsh sites may also differ, which could affect carbon dioxide emissions, decomposition, and mineralization rates.

In contrast to our findings of lower belowground biomass, lower abundances of roots and rhizomes, and lower organic matter accumulation (Fig. 5) in disappearing organic-rich marshes, an increase in coarse roots, rhizomes, and peat was quantified in a 12-year nitrogen-fertilized salt marsh in the southeastern United States that was dominated by depositional processes (Goat Island, South Carolina; Davey et al. 2011). In minerogenic marshes dominated by sediment deposition, nutrient additions may stimulate biogenic processes (e.g., coarse root and rhizome production) and the buildup of refractory organic matter (Day et al. 2008, Davey et al. 2011). Whereas in organic rich marshes dominated by biogenic processes, nitrogen fertilization often results in elevated decomposition rates, decreased root and rhizome production, and loss of organic matter and peat (Darby and Turner 2008, Turner et al. 2009, Davey et al. 2011, Deegan et al. 2012).

A loss in the root and rhizome belowground mass and more waterlogged peat could contribute to local subsidence, and ultimate marsh drowning (DeLaune et al. 1983a, b, Fagherazzi et al. 2012, Kirwan and Guntenspergen 2012). When stress (e.g., elevated nutrients, increases in the duration and frequency of flooding, elevated sulfides) becomes too extreme, plants die, which 
results in rapid loss of root volume and mass due to loss of root turgor and belowground decomposition (DeLaune et al. 1994). At the high-marsh interior locations of Black Bank, the lowest values of peat volume (33.9\%) and peat wet mass $\left(51.7 \mathrm{~kg} / \mathrm{m}^{2}\right)$ were reported at the 10 $20 \mathrm{~cm}$ depth, supporting the hypothesis that peat deterioration contributes to marsh loss at interior locations. Hartig et al. (2002) earlier reported accelerated loss in interior locations of Jamaica Bay marshes, and attributed it to expanding channel networks and ponding.

The deteriorating Black Bank site showed significant differences in above- and belowground morphology of stems and rhizomes compared to the stable JoCo site. The allocation of resources to the aboveground stems was enhanced, as evidenced by the significantly longer stems and greater above-to-belowground biomass ratios in the Black Bank marsh samples. The Black Bank site is $17 \mathrm{~cm}$ below MHW. It has been shown in mesocosms and model simulations that a natural feedback of marsh vegetation to low elevation is increased aboveground production and stem elongation, which traps mineral and organic particulates and adds plant litter to the surface, contributing to vertical accretion (Morris et al. 2002, Kirwan et al. 2008, Mudd et al. 2009, Fagherazzi et al. 2012). The diameters of the rhizomes were significantly larger at the Black Bank site, perhaps to support the increased aboveground biomass in the waterlogged, mucky soils. The deteriorating marshes have more waterlogged and reduced soils, and the increase in diameter of the rhizomes may also facilitate oxygen release into the rhizosphere (Teal and Kanwisher 1966). Last, the volume of large rhizomes (see Plate 1) could also contribute physically to marsh surface elevation.

Salt marsh islands throughout the Jamaica Bay Estuary are converting to unvegetated intertidal and subtidal habitat at an alarming rate (over $60 \%$ of vegetated marsh islands between 1951 and 2003 has been lost [National Park Service 2007, Hartig et al. 2002]), yet we note that the estuary's JoCo marsh appears stable, and is composed mostly of vegetated habitat. The JoCo Marsh is presently at a higher elevation than at the Black Bank and Big Egg marshes, and this may have been the case historically, thus the frequency and duration of flooding by nutrient-enriched waters is less; the JoCo sediments, however, do reflect a long history of nitrogen loading (Fig. 3). The system-wide variability in hydrodynamics, bathymetry, and sediment transport, coupled with an intense history of urban activities throughout the estuary (e.g., dredging, filling, urban runoff), are undoubtedly contributing to differences in marsh platform elevations and responses of the marsh islands to sediment delivery, nutrient loading, flooding and drainage, and other factors that influence marsh development processes (Hartig et al. 2002, Kolker 2005, Peteet et al. 2006, Swanson and Wilson 2008).

\section{Marsh elevation and changes in peat composition}

The rates of marsh surface elevation change for the JoCo $(5.1 \mathrm{~mm} / \mathrm{yr})$ and Black Bank ( $4.9 \mathrm{~mm} / \mathrm{yr})$ marshes approximated or were greater than the long-term relative rate of sea level rise estimated from the tide gauge at Sandy Hook, New Jersey (1932-2011; $4.1 \mathrm{~mm} /$ yr; data available online). ${ }^{9}$ Apparently the Black Bank marsh is keeping pace with sea level rise (2002-present) due to accretion of material on the marsh surface and swelling (dilation) of peat. The inventories (2004-2006) of particle-reactive natural radionuclides ${ }^{7} \mathrm{Be}$ and ${ }^{234} \mathrm{Th}$ suggest that there is an import of sediment from the New York Bight into Jamaica Bay, which may contribute to accretion on the marsh surface (Renfro et al. 2010). In addition, peat swelling and production of large diameter rhizomes at Black Bank may allow for the marsh to keep pace with sea level rise. Marsh surface elevation can rise, at least temporarily, in direct response to sediment dilation or swelling (Cahoon et al. 2011); when marsh sediment dilates, the bulk volume of the sediment increases by an amount equal to the volume of water added (Nuttle et al. 1990). However, continuous waterlogging results in a lack of consolidation, lower shear strength, and anoxic conditions with sulfide toxicity, all likely contributing to ultimate elevation loss and peat collapse as observed at Big Egg and portions of the Black Bank marshes. We think these results are similar to those reported for the Bayou Chitigue marsh in Louisiana (Day et al. 2011). Although it appears the Jamaica Bay marshes are keeping pace with historic sea level rise rates, in the northeastern United States over the past three decades increases in the sea level rise rates are three to four times higher than the global average (Boon 2012, Sallenger et al. 2012). It is expected that an accelerated rate of sea level rise will further stress the ability of marshes to maintain elevation.

Averaged across both sites, the creek-bank locations had significantly lower peat volume and percent soil organic matter (Fig. 5a) than the mid- and high-marsh interior locations. We observed fracturing and disintegration of the creek-bank peat, especially at Black Bank and Big Egg sites, which may be a source of organic particulates that accrete on surviving marsh surfaces. Deegan et al. (2012) reported fracturing and slumping of the creek-bank edge and a corresponding increase in fine organic matter in tidal channels associated with the fertilized marsh creek. Sediment erosion from one portion of a marsh system (e.g., creek-bank edge, tidal channel) can be a source of sediment to a surviving marsh area, thereby contributing to vertical accretion (Kirwan et al. 2008, Fagherazzi et al. 2012).

The CT peat particle density was significantly greater at the Black Bank marsh compared to the JoCo marsh, suggesting that peat at the Black Bank marsh is highly waterlogged and decomposed. Similarly, others have

${ }^{9} \mathrm{http}: / /$ tidesandcurrents.NOAA.gov 
reported the disappearing marshes at Jamaica Bay as having excessive peat porosity and a "soupy" consistency (Hartig et al. 2002). Peat swelling might contribute to the positive elevation trend at the Black Bank marsh. Although the rate of elevation change, accretion rates, and peat volume (Fig. 4b) at Black Bank were similar to the JoCo marsh, the Black Bank marsh had significantly lower soil shear strength (Fig. 5b), especially at the $30-$ $50 \mathrm{~cm}$ depths. Even though the Black Bank marsh is currently keeping pace with sea level, both it $(17 \mathrm{~cm}$ below MHW) and Big Egg marsh (55 cm below MHW) have diminishing elevation capital (i.e., the marsh surface is becoming lower relative to MHW; Cahoon and Guntenspergen 2010). Given the low soil shear strength and saturated conditions that contribute to reduced root production due to sulfide toxicity (King et al. 1982, Mendelssohn and Morris 2000, Kolker 2005), peat collapse is likely leaving some Jamaica Bay marshes (e.g., Black Bank, Big Egg) at suboptimal elevations, exacerbating the effects of increased decomposition rates and losses of organic matter that may be related to nutrient enrichment.

At the restored Big Egg site, sediment was added to raise the elevation of the deteriorating marsh (i.e., gain elevation capital). Our CT imaging and morphological soil observations at the restored Big Egg site in 2006 showed roots, rhizomes, and $10 \%$ fresh soil organic materials accumulating in the surface sediments (Table 1, Fig. 4), contributing to the recovery of the marsh. In addition, more intense restoration efforts in the Jamaica Bay Estuary are ongoing using dredge material that was slurried and pumped onto the marsh surface at Elders Point East (15.8 ha) and Elders Point West (13.4 ha; Rafferty et al. 2010). The reported rates of marsh loss in the Jamaica Bay Estuary average $13 \mathrm{ha} / \mathrm{yr}$, and even the apparently stable JoCo marsh has begun to show accelerated rates of marsh loss, losing 2 ha/yr from 1989-2003, five times higher than the average rate for the prior period 1974-1989 (0.4 ha/yr; National Park Service 2007).

Cultural eutrophication, climate change (e.g., accelerated sea level rise; rising air and soil temperatures; increases in storm and drought events), and human activities that alter the sediment supply and hydrodynamics of salt marshes in urban watersheds may result in accelerated losses of marsh area as is now occurring within Jamaica Bay and elsewhere (e.g., Hartig et al. 2002, Turner et al. 2009, Rafferty et al. 2010, Deegan et al. 2012). Understanding the effects of multiple stressors, including nutrient (nitrogen and/or phosphorus) enrichment, on soil structure, organic matter accumulation, and marsh elevation will afford managers and stewards an informed opportunity to maintain and restore coastal marshes in urban estuaries.

\section{ACKNOWLEDGMENTS}

We are grateful for the stable isotope expertise of Rick McKinney, field and logistic assistance of Matt Holt, Liz Gamez, and Jeff Hollister, GIS expertise of Mike Charpentier, and graphic creations by Patricia DeCastro. Jim Heltshe provided statistical guidance throughout the study. Dan Campbell, Rick McKinney, Autumn Oczkowski, Marty Chintala, and Glen Thursby provided helpful and insightful comments on an early draft of the manuscript. Mention of trade names or commercial products does not constitute endorsement or recommendation for use by the U.S. EPA, USGS, or NPS. This report, ORD Tracking Number ORD003104\#, has been reviewed technically by the U.S. EPA's Office of Research and Development, National Health and Environmental Effects Research Laboratory, Atlantic Ecology Division, Narragansett, Rhode Island, and approved for publication. Approval does not signify that the contents necessarily reflect the views and policies of the U.S. EPA or NPS.

\section{Literature Cited}

Anisfeld, S. C., and T. D. Hill. 2012. Fertilization effects on elevation change and belowground carbon balance in a Long Island Sound tidal marsh. Estuaries and Coasts 35:201-211.

Appleby, P. G., and F. Oldfield. 1978. The calculation of lead210 dates assuming a constant rate of supply of unsupported ${ }^{210} \mathrm{~Pb}$ to the sediment. Catena $5: 1-8$.

Aspila, K. I. H. Agemain, and A. Chau. 1976. A semiautomated method for the determination of inorganic, organic and total phosphorus in sediments. Analyst 101:187-197.

Bannon, R. O., and C. T. Roman. 2008. Using stable isotopes to monitor anthropogenic nitrogen inputs to estuaries. Ecological Applications 18:22-30.

Bayor, R. H., and T. J. Meagher. 1996. The New York Irish. Johns Hopkins University Press, Baltimore, Maryland, USA.

Benotti, M. J., M. Abbene, and S. A. Terracciano. 2007. Nitrogen loading in Jamaica Bay, Long Island, New York: predevelopment to 2005. U.S. Geological Survey Scientific Investigations Report 2007-5051. http://pubs.usgs.gov/sir/ $2007 / 5051 /$

Blazejewski, G., M. H. Stolt, A. J. Gold, and P. M. Groffman. 2005. Macro- and micromorphology of subsurface carbon in riparian zone soils. Soil Science Society of America Journal 69:1320-1329.

Boon, J. D. 2012. Evidence of sea level acceleration at US and Canadian tide stations, Atlantic Coast, North America. Journal of Coastal Research 28:1437-1445.

Boumans, R. M. J., and J. W. Day, Jr. 1993. High precision measurements of sediment elevation in shallow coastal areas using sediment-erosion table. Estuaries 16:375-380.

Bullock, P., N. Federoff, A. Jongerius, G. Stoops, T. Tursina, and U. Babel. 1985. Handbook for thin section description. Waine Research Publications, Wolverhampton, UK.

Cahoon, D. R., and G. R. Guntenspergen. 2010. Climate change, sea-level rise, and coastal wetlands. National Wetlands Newsletter 32:8-12.

Cahoon, D. R., J. C. Lynch, B. C. Perez, B. Segura, R. D. Holland, C. Stelly, G. Stephenson, and P. Hensel. 2002. High precision measurements of wetland sediment elevation: II. The rod surface elevation table. Journal of Sedimentary Research 72:734-739.

Cahoon, D. R., B. C. Perez, B. D. Segura, and J. C. Lynch. 2011. Elevation trends and shrink-swell response of wetland soils to flooding and drying. Estuarine, Coastal and Shelf Science 91:463-474.

Cahoon, D. R., D. J. Reed, and J. W. Day, Jr. 1995. Estimating shallow subsidence in microtidal salt marshes of the southeastern US: Kaye and Barghoorn revisited. Marine Geology 128:1-9.

Cahoon, D. R., D. J. Reed, A. S. Kolker, M. M. Brinson, J. C. Stevenson, S. Riggs, R. Christian, E. Reyes, C. Voss, and D. Kunz. 2009. Coastal wetland sustainability. Pages 57-72 in Coastal sensitivity to sea-level rise: a focus on the MidAtlantic Region. Synthesis and assessment product 4.1. U.S. 
Climate Change Science Program and the Subcommittee on Global Change Research, Washington, D.C., USA.

Cahoon, D. R., and R. E. Turner. 1989. Accretion and canal impacts in a rapidly subsiding wetland II: Feldspar marker horizon technique. Estuaries 12:260-268.

Castro, P., I. Valiela, and H. Freitas. 2007. The use of sedimentary $\% \mathrm{C}, \% \mathrm{~N}$, del $\mathrm{N} 15$, and $\mathrm{Pb}$ concentrations to assess historical changes in anthropogenic influence on Portuguese estuaries. Environmental Pollution 147:706-712.

Cochran, J. K., J. Hirschberg, J. Wang, and C. Dere. 1992. Atmospheric deposition of metals to coastal waters (Long Island Sound, New York, USA): evidence from saltmarsh deposits. Estuarine, Coastal and Shelf Science 46:503-522.

Craft, C. 2007. Freshwater input structures soil properties, vertical accretion, and nutrient accumulation of Georgia and U.S. tidal marshes. Limnology and Oceanography 52:12201230.

Damon, A. L. 1981. A look at the record: the facts behind the current controversy over immigration. American Heritage Magazine 33(1):50-56.

Darby, F. A., and R. E. Turner. 2008. Effects of eutrophication to salt marsh roots, rhizomes, and soils. Marine Ecological Progress Series 363:63-70.

Davey, E., C. Wigand, R. Johnson, K. Sundberg, J. Morris, and C. Roman. 2011. Use of computed tomography imaging for quantifying coarse roots, rhizomes, peat, and particle densities in marsh soils. Ecological Applications 21:21562171.

Day, J. W., R. Christian, D. M. Boesch, A. Yaňez-Arancibia, J. T. Morris, R. R. Twilley, L. Naylor, L. Schaffner, and C. Stevenson. 2008. Consequences of climate change on the ecogeomorphology of coastal wetlands. Estuaries and Coasts 31:477-491.

Day, J. W., G. P. Kemp, D. J. Reed, D. R. Cahoon, R. M. Boumans, J. M. Suhayda, and R. Gambrell. 2011. Vegetation death and rapid loss of surface elevation in two contrasting Mississippi delta salt marshes: the role of sedimentation, autocompaction and sea-level rise. Ecological Engineering 37:229-240.

Deegan, L. A., D. S. Johnson, R. S. Warren, B. Peterson, J. W. Fleeger, S. Fagherazzi, and W. Wollheim. 2012. Coastal eutrophication as a driver of marsh loss. Nature 490:388-392.

DeLaune, R. D., R. Baumann, and J. G. Gosselink. $1983 a$. Relationships among vertical accretion, coastal submergence, and erosion in a Louisiana Gulf Coast marsh. Journal of Sedimentary Petrology 53:147-157.

DeLaune, R. D., J. Nyman, and W. Patrick. 1994. Peat collapse, ponding and wetland loss in a rapidly submerging coastal marsh. Journal of Coastal Research 10:1021-1030.

DeLaune, R. D., C. J. Smith, and W. H. Patrick, Jr. 1983 b. Relationship of marsh elevation, redox potential, and sulfide to Spartina alterniflora productivity. Soil Science Society of America Journal 47:930-935.

Fagherazzi, S., et al. 2012. Numerical models of salt marsh evolution: ecological, geomorphic, and climatic factors. Reviews of Geophysics 50:RG1002.

Forstall, R. L. 1996. Population of states and counties of the United States: 1790 to 1990. U.S. Bureau of the Census, Washington, D.C., USA.

Greene, E. B., and V. D. Harrington. 1932. American population before the Federal Census of 1790. Columbia University Press, New York, New York, USA.

Hartig, E. K., V. Gornitz, A. Kolker, F. Mushacke, and D. Fallon. 2002. Anthropogenic and climate-change impacts on salt marshes of Jamaica Bay, New York City. Wetlands 22:71-89.

Heiri, O., A. F. Lotter, and G. Lemcke. 1999. Loss on ignition as a method for estimating organic and carbonate content in sediments: reproducibility and comparability of results. Journal of Paleolimnology 25:101-110.
Howes, B. L., W. H. Dacey, and J. M. Teal. 1985. Annual carbon mineralization and below-ground production of Spartina alterniflora in a New England salt marsh. Ecology 66:595-605.

Jackson, K. T. 1985. Crabgrass frontier: the surburbanization of the United States. Oxford University Press, New York, New York, USA.

Jowsey, P. C. 1966. An improved peat sampler. New Phytologist 65:245-248.

Kellogg, C. E. 1956. The soils that support us. MacMillan, New York, New York, USA.

King, G. M., M. J. Klug, R. G. Wiegert, and A. G. Chalmers. 1982. Relation of soil water movement and sulfide concentration to Spartina alterniflora production in a Georgia saltmarsh. Science 218 (4567):61-63.

Kirwan, M. L., and G. R. Guntenspergen. 2012. Feedbacks between inundation, root production, and shoot growth in a rapidly submerging brackish marsh. Journal of Ecology 100:764-770.

Kirwan, M. L., G. R. Guntenspergen, A. D'Alpaos, J. T. Morris, S. M. Mudd, and S. Temmerman. 2010. Limits of the adaptability of coastal marshes to rising sea level. Geophysical Research Letters 37:L23401.

Kirwan, M. L., A. B. Murray, and W. S. Boyd. 2008. Temporary vegetation disturbance as an explanation for permanent loss of tidal wetlands. Geophysical Research Letters 35:L05403.

Kolker, A. S. 2005. The impacts of climate variability and anthropogenic activities on salt marsh accretion and loss on Long Island. Dissertation. Marine Science Research Center, Stony Brook University, Stony Brook, New York, USA.

Krishnaswami, S., L. K. Benninger, R. C. Aller, and K. L. Von Damm. 1980. Atmospherically-derived radionuclides as tracers of sediment mixing and accumulation in near-shore marine and lake sediments: evidence from ${ }^{7} \mathrm{Be},{ }^{210} \mathrm{~Pb}$, ${ }_{239,240} \mathrm{Pu}$. Earth and Planetary Science Letters 47:307-318.

Langley, J. A., K. L. McKee, D. R. Cahoon, J. A. Cherry, and J. P. Megonigal. 2009. Elevated $\mathrm{CO}_{2}$ stimulates marsh elevation gain, counterbalancing sea-level rise. Proceedings of the National Academy of Sciences USA 106:6182-6186.

Mack, M. C., E. A. G. Schuur, M. S. Bret-Harte, R. Shaver, and S. Chaplin III. 2004. Ecosystem carbon storage in arctic tundra reduced by long-term nutrient fertilization. Nature 431:440-443.

Maren, V., and U. Struck. 1997. Stable nitrogen and carbon isotopes as indicator of eutrophication of the Oder River (Baltic sea). Marine Chemistry 59:35-49.

Mariotti, A. 1983. Atmospheric nitrogen is a reliable standard for natural ${ }^{15} \mathrm{~N}$ abundance measurements. Nature 303:685687.

McClelland, J. W., and I. Valiela. 1998. Linking nitrogen in estuarine producers to land derived sources. Limnology and Oceanography 43:577-585.

McClelland, J. W., I. Valiela, and R. H. Michener. 1997. Nitrogen stable isotope signatures in estuarine food webs: a record of increasing urbanization in coastal watersheds. Limnology and Oceanography 42:930-937.

McCullough, D. 2005. 1776. Simon and Schuster Paperbacks, New York, New York, USA.

McKinney, R., W. G. Nelson, M. A. Charpentier, and C. Wigand. 2001. Ribbed mussel nitrogen isotope signatures reflect nitrogen sources in coastal salt marshes. Ecological Applications 11:203-214.

Mendelssohn, I. A., and J. T. Morris. 2000. Eco-physiological controls on the productivity of Spartina alterniflora Loisel. Pages 59-80 in M. P. Weinstein and D. A. Kreeger, editors. Concepts and controversies in tidal marsh ecology. Kluwer Academic Publishers, Boston, Massachusetts, USA.

Morris, J. T., and P. M. Bradley. 1999. Effects of nutrient loading on the carbon balance of coastal wetland sediments. Limnology and Oceanography 44:699-702. 
Morris, J. T., P. V. Sundareshwar, P. T. Nietch, B. Kjerfve, and D. R. Cahoon. 2002. Responses of coastal wetlands to rising sea level. Ecology 83:2869-2877.

Mudd, S. M., S. M. Howell, and J. T. Morris. 2009. Impact of dynamic feedbacks between sedimentation, sea-level rise, and biomass production on near surface marsh stratigraphy and carbon accumulation. Estuarine Coastal and Shelf Science 82(3):377-389.

National Park Service. 2007. An update on the disappearing salt marshes of Jamaica Bay, New York. Prepared by Gateway National Recreation Area, NPS, US DOI and the Jamaica Bay Watershed Protection Plan Advisory Committee. National Park Service, Washington, D.C., USA.

New York City Department of Environmental Protection. 2007. Jamaica Bay watershed protection plan, volume 1. http:// www.nyc.gov/html/dep/pdf/jamaica_bay/vol-1-complete.pdf

Nuttle, W. K., H. F. Hemond, and K. E. Stolzenbach. 1990. Mechanisms of water storage in salt marsh sediments: the importance of dilation. Hydrological Process 4:1-13.

O'Shea, M. L., and T. M. Brosnan. 2000. Trends in indicators of eutrophication in western Long Island Sound and the Hudson-Raritan estuary. Estuaries 23:877-901.

Peteet, D., D. Pederson, D. Kurdyla, and T. Guilderson. 2006. Hudson River paleoecology from marshes. Pages 113-128 in J. R. Waldman, K. E. Limburg, and D. Strayer, editors. Hudson River fishes and their environment. Monograph. American Fisheries Society, Bethesda, Maryland, USA.

Qualls, R. G., and C. J. Richardson. 2008. Decomposition of litter and peat in the Everglades: The influence of $\mathrm{P}$ concentrations. Pages 441-459 in C. J. Richardson, editor. The Everglades experiments. Springer, New York, New York, USA.

Rafferty, P., J. Castagna, and D. Adamo. 2010. Restoration Journal: building partnerships to restore an urban marsh ecosystem at Gateway National Recreation area. Park Science Winter 2010-2011 27(3):34-41.

Renfro, A., J. K. Cochran, D. J. Hirschberg, and S. L. Goodbred. 2010. Natural radionuclides $\left({ }^{234} \mathrm{Th},{ }^{7} \mathrm{Be}\right.$ and ${ }^{210} \mathrm{~Pb}$ ) as indicators of sediment dynamics in Jamaica Bay, New York. Natural Resource Technical Report NPS/NERO/ NRTR-2010/324. U.S. Department of the Interior National Park Service, Fort Collins, Colorado, USA.

Sallenger, A. H., K. S. Doran, and P. A. Howd. 2012. Hotspot of accelerated sea-level rise on the Atlantic coast of North America. Nature Climate Change 2:884-888.

Schoeneberger, P. J., D. A. Wysocki, E. C. Benham, and W. D. Broderson, editors. 2002. Field book for describing and sampling soils. Version 2.0. Natural Resources Conservation Service, National Soil Survey Center, Lincoln, Nebraska, USA.

Stolt, M. H., and D. Lindbo. 2010. Soil organic matter. Pages 129-148 in G. Stoops, V. Marcelino, and F. Mees, editors. Interpretation of micromorphological features of soils and regoliths. Elsevier, Amsterdam, The Netherlands.

Stoops, G. 2003. Guidelines for analysis and description of soil and regolith thin sections. Soil Science Society of America, Madison, Wisconsin, USA.
Strickland, J., and T. Parsons. 1972. A practical handbook of seawater analysis. Bulletin 167. Fisheries Research Board of Canada, Ottawa, Ontario, Canada.

Struck, U., K. Emeis, M. Voss, C. Christiansen, and H. Kunzendorf. 2000. Records of southern and central Baltic Sea eutrophication in $\delta 13 \mathrm{C}$ and $\delta 15 \mathrm{~N}$ of sedimentary organic matter. Marine Geology 164:157-171.

Sundareshwar, P. V., J. T. Morris, E. K. Koepfler, and B. Fornwalt. 2003. Phosphorus limitation of coastal ecosystem processes. Science 299:563-565.

Swanson, R. L., A. S. West-Valle, and C. J. Decker. 1992. Recreation vs. waste disposal: the use and management of Jamaica Bay. Long Island Historical Journal 5(1):21-41.

Swanson, R. L., and R. E. Wilson. 2008. Increased tidal ranges coinciding with Jamaica Bay development contribute to marsh flooding. Journal of Coastal Research 24(6):15651569.

Teal, J. M., and J. W. Kanwisher. 1966. Gas transport in the marsh grass, Spartina alterniflora. Journal of Experimental Botany 17:355-361.

Turner, R. E. 2011. Beneath the saltmarsh canopy: loss of soil strength with increasing nutrient loads. Estuaries and Coasts 34:1084-1093.

Turner, R. E., B. L. Howes, J. M. Teal, C. S. Milan, E. M. Swenson, and D. D. Goehringer-Toner. 2009. Salt marshes and eutrophication: an unsustainable outcome. Limnology and Oceanography 54:1634-1642.

Turner, R. E., C. S. Milan, and E. M. Swenson. 2006. Recent volumetric changes in saltmarsh soils. Estuarine, Coastal and Shelf Science 69(3-4):352-359.

U.S. Census. 2000. TIGER/Line Shapefile, 2000, New York. Scale: 1:100,000. U.S. Department of Commerce, U.S. Census Bureau, Geography Division, Washington, D.C., USA.

Valiela, I., J. M. Teal, and N. Y. Persson. 1976. Production and dynamics of experimentally enriched salt marsh vegetation: belowground biomass. Limnology and Oceanography 21:245-252.

Wigand, C. 2008. Coastal salt marsh community change in Narragansett Bay in response to cultural eutrophication. Pages 499-522 in A. Desbonett and B. A. Costa-Pierce, editors. Science for ecosystem-based management. Springer, New York, New York, USA.

Wigand, C., P. Brennan, M. Stolt, M. Holt, and S. Ryba. 2009. Soil respiration rates in coastal marshes subject to increasing watershed nitrogen loads in southern New England, USA. Wetlands 29:952-963.

Wigand, C., R. McKinney, M. Chintala, M. Charpentier, and G. Thursby. 2003. Relationships of nitrogen loadings, residential development, and physical characteristics with plant structure in New England salt marshes. Estuaries 26:1494-1504.

Wigand, C., and C. T. Roman. 2012. North Atlantic coastal tidal wetlands. Pages 13-28 in Wetland habitats of North America: ecology and conservation concerns. D. Batzer and A. Baldwin, editors. University of California Press, Berkeley, California, USA. 